A Novel Field of Research:

Bioorganometallic Chemistry, Origins, and Founding Principles

Gérard Jaouen, Wolfgang Beck, and Michael J. McGlinchey
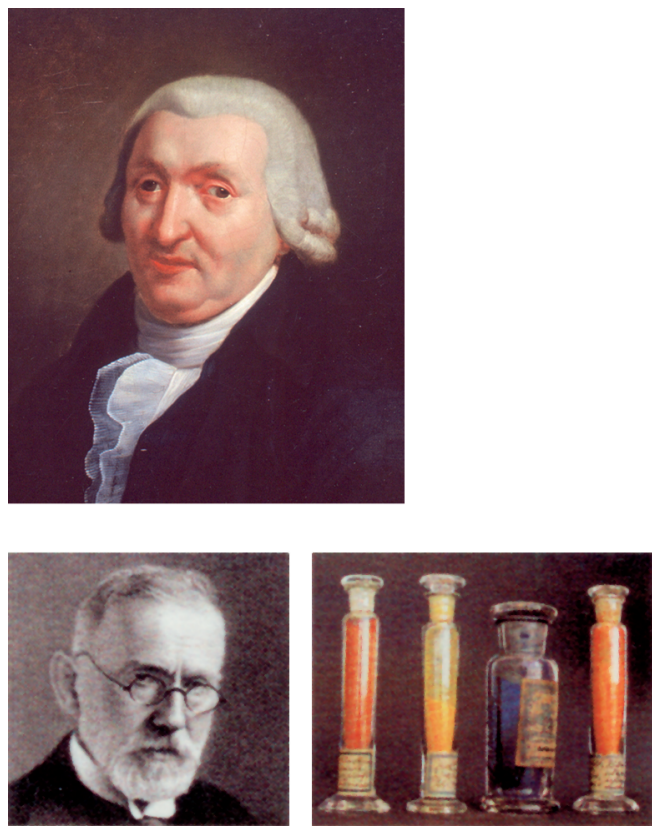

The two founding fathers.

Top: Organometallic chemistry: the French L.-C. Cadet de Gassicourt (1713-1799; courtesy of ). Flahaut). Bottom: Organometallic drugs: the German P. Ehrlich (1854-1915; from a German postage stamp).

1.1

Introduction

In 1985 the term bioorganometallic chemistry was first applied to the synthesis and study of organometallic species of biological and medical interest $[1,2]$. It became apparent at that time that a critical mass of separate but novel results had

Bioorganometallics: Biomolecules, Labeling, Medicine. Edited by Gérard Jaouen

Copyright (C) 2006 Wiley-VCH Verlag GmbH \& Co. KGaA, Weinheim

ISBN: 3-527-30990-X 


\section{A Novel Field of Research: Bioorganometallic Chemistry, Origins, and Founding Principles}

been reached that required a unifying term to identify this type of research as a whole. The term in fact covered complexes formed using classical organometallic ligands (e.g. CO, alkyls, $\pi$-bonded species) or biomolecules (steroids, amino acids, sugars, peptides, DNA, vitamins, enzymes, antibodies) attached by direct metalcarbon linkages, but all having in common their ability to play a role in biological processes. This by no means exhaustive list should give an idea of the potential scope of this field [3-15].

The idea of combining organometallic and biological components had of course occurred before to a number of researchers, with varying results. This opening chapter aims to address this period of induction and emergence, viewed from today's perspective, and to attempt to show the development of the founding principles of this field, which is multidisciplinary by definition and thus requires advances on several fronts for its own development. In this respect, it is remarkable that one of the factors leading to the explosion of the field was the enhanced understanding of the metal-carbon $(\mathrm{M}-\mathrm{C})$ bond, with the result that all studies up to and including the structure of vitamin $B_{12}$ consider only $\sigma$ bonds [16-18]. However, following the discovery of ferrocene and its sandwich structure [19-21], we see the establishment of a theoretical basis for the understanding of new types of M-C bonds $(\sigma, \pi$ and $\delta$ ) such as, for example, those of metallocenes, metal carbonyls or metal carbenes (Scheme 1.1).

This structural diversity provided a wealth of new reactivity for chemical researchers and gave rise to the development of transition-metal organometallic chemistry in general, and later to bioorganometallic chemistry as we know it today [22-24]. The positioning of bioorganometallic chemistry is summarized schematically in Scheme 1.2.

General

formula

Metal carbonyl:
(Mond, Berthelot,
Hieber)

Metal alkyl:

(Pope)

Metal carbene:

(Fischer, Schrock)

Metallocene:

(Wilkinson, Fischer)

Metal hydride:

(Hieber, Cotton)<smiles>[M]C(=O)CC(=O)O</smiles>
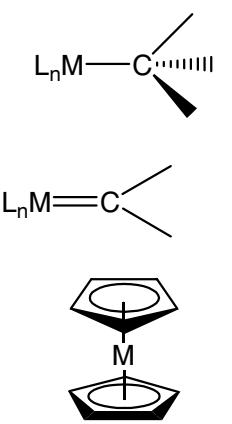

$\mathrm{L}_{\mathrm{n}} \mathrm{M}-\mathrm{H}$

\section{Example}

$\mathrm{Ni}(\mathrm{CO})_{4}, \mathrm{Fe}(\mathrm{CO})_{5}$

$\left(\mathrm{CH}_{3}\right)_{3} \mathrm{Pt}-\mathrm{I}$

$(\mathrm{CO})_{4} \mathrm{Co}-\mathrm{CH}_{3}$<smiles></smiles>

$\mathrm{Fe}\left(\mathrm{C}_{5} \mathrm{H}_{5}\right)_{2}$

(Ferrocene)

$\mathrm{H}_{2} \mathrm{Fe}(\mathrm{CO})_{4}$

$\mathrm{HCo}(\mathrm{CO})_{4}$,

$\left(\mathrm{C}_{5} \mathrm{H}_{5}\right)_{2} \mathrm{ReH}$

Scheme 1.1 Transition metal organometallic compounds. 


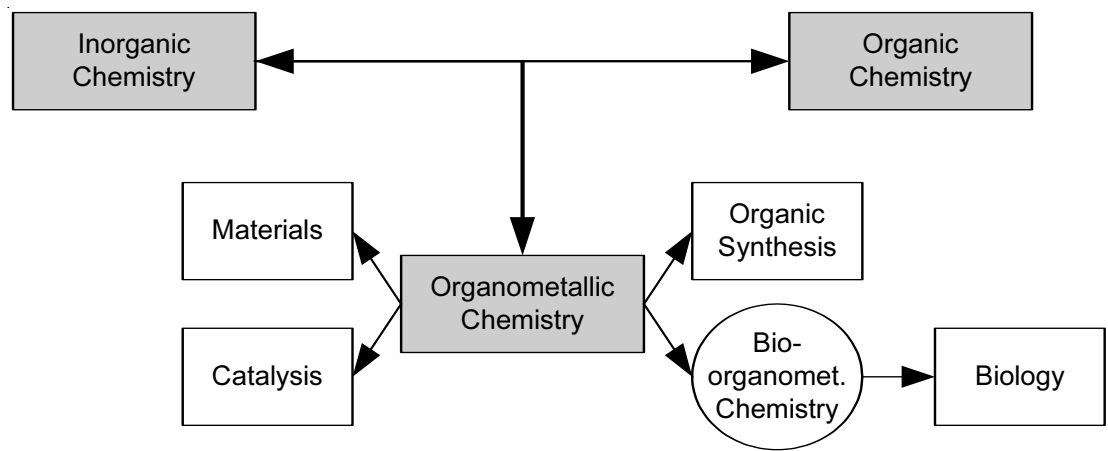

Scheme 1.2 Relationship of organometallic chemistry

(complexes with direct metal-carbon bonds) to the principal related disciplines.

With the perspective of time, it is easier to see how the profusion of novel functions, novel structures and thus novel properties led to the phenomenal success of transition-metal organometallic chemistry in the second half of the twentieth century. The most thoroughly explored fields of application were firstly in the area of catalysis, with ground-breaking reactions such as Ziegler-Natta polymerization, asymmetric synthesis (Sharpless, Noyori, Kagan, Knowles) and olefin metathesis (Grubbs, Schrock), as well as organic synthesis, with a number of advances such as those involving C-C coupling (Stille, Suzuki, Heck, Pauson), and access to new materials and polymers (Kaminski, Marks, Brintzinger). It was not until later, since it required the integration of two disciplines as well as the ability to control the behavior of organometallic complexes in water, that bioorganometallic chemistry, the subject of the current chapter, appeared on the scene. Recent expansion has been rapid and at least five major fields of activity can now be identified (Scheme 1.3). A brief history of each will be followed by a deeper discussion in the later chapters of the aspects of these areas that have already been elucidated.

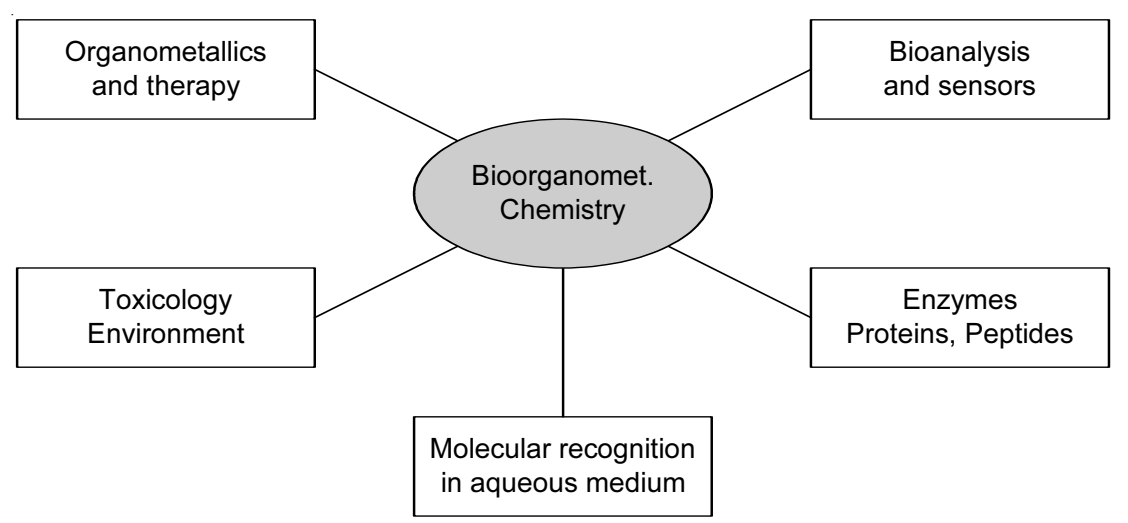

Scheme 1.3 Principal fields of research activity in bioorganometallic chemistry. 
1.2.1

\section{The Founding Father}

The pharmaceutical industry at the present time is in a relative lull in its ongoing search for truly innovative, therapeutically useful molecules. After witnessing the incredible success of antibiotics, and while awaiting the fulfilment of hopes placed in gene therapy, it is important to continue the search for innovative concepts. The study of the uses of organometallic complexes in medicine could be one of these innovative approaches, owing to the unusual reactivity of these entities. Seen from this perspective, organometallic chemistry had an appropriate genesis, arising from the mind of a distinguished pharmacist of the Enlightenment, a contemporary of Priestley and Lavoisier. This pharmacist was a member of the French Académie Royale des Sciences and had a surgery at 115, rue St Honoré in Paris.

Louis-Claude Cadet de Gassicourt (1713-1799) left a fascinating legacy; the son he recognized in 1769, Charles-Louis, was actually the illegitimate offspring of King Louis XV (and Marie-Thérèse Boisselet). On the other hand, he could never have known that he is now regarded as the father of organometallic chemistry. On August 27, 1758, he submitted a paper to the Académie Royale des Sciences which dealt with "Cadet's fuming liquid”, and which was published in 1760 [25]. This heavy brown liquid is highly toxic, smells strongly of garlic, and spontaneously bursts into flame when exposed to air. It comprises mainly cacodyl oxide $\left(\mathrm{Me}_{2} \mathrm{As}\right)_{2} \mathrm{O}$, but also contains other cacodyl compounds, such as dicacodyl $\left(\mathrm{Me}_{2} \mathrm{As}\right)_{2}$. For personal reasons, Cadet never went back to this seminal work. The unhappiness of his conjugal life led him to squander his money, among other things on the ladies of the nearby Palais Royal. He left practically no inheritance to his adopted son, other than a good education. This at least allowed the young man to become the pharmacist of the Emperor Napoleon and thus to participate in his campaigns in Europe [26]. The story is perhaps typical of many in those turbulent years of French history, when fates collided, and fortunes were made and unmade.

$$
\mathrm{As}_{2} \mathrm{O}_{3}+4 \mathrm{CH}_{3} \mathrm{COOK} \rightarrow \text { "Cadet's fuming liquid" }
$$

In Cadet's day there was no way to explain this reaction, obtained by distilling a mixture of arsenic oxide and "foliated earth of tartar" (potassium acetate), as part of a study on invisible inks. In fact, it was not until almost 80 years later, with the work of Bunsen, that the explanation was forthcoming: these reaction conditions led to the production of "cacodyls" [27, 28]. Cacodyl is derived from the Greek $\kappa \alpha \kappa \omega \delta \eta \varsigma$ kakodes meaning evil-smelling. In 1834, J. B. Dumas was forbidden by the administration of the Ecole Polytechnique, located in central Paris, to pursue his research on the fuming liquid. The University at Marburg was somewhat 
more accommodating. They allowed Bunsen (1811-1899) to use a thatch-covered hunting cabin in the middle of the woods to study these cacodyl species from 1837 to 1842 , and so identify their organometallic nature, i.e. possession of a direct $\mathrm{M}-\mathrm{C}$ bond [27, 29-31].

A number of cacodyl derivatives were subsequently discovered, notably various cacodylates used in the first half of the twentieth century as tonics and fortifying medicines for conditions associated with a lowering of hemoglobin levels (tuberculosis, multiple sclerosis, malaria, etc.) [28].

1.2.2

\section{The First Significant Organometallic Drug}

The negative effects of arsenic have been known throughout history (e.g. Nero, or the Borgias). In seventeenth-century France, white arsenic, $\mathrm{As}_{2} \mathrm{O}_{3}$, acquired the name of "poudre de succession" (inheritance powder). Advances in organometallic chemistry were made throughout the nineteenth century in Europe. For example, Bunsen and Frankland described alkylarsines and alkylmercury compounds, Löwig synthesized $\left(\mathrm{C}_{2} \mathrm{H}_{5}\right)_{4} \mathrm{~Pb}$, Friedel and Crafts investigated organochlorosilanes, and Schützenberger prepared $\left[\mathrm{Pt}(\mathrm{CO}) \mathrm{Cl}_{2}\right]_{2}$. These reports led Ehrlich (1854-1915) and others to realize that organometallic compounds of arsenic could be less toxic, and easier to manipulate, than their inorganic counterparts. The idea was a novel one, but its implementation proved difficult, requiring the collaboration of a chemist, Bertheim, and a biologist, Sacachiro Hata. In turn, the systematic medical application of organoarsenicals as antiparasitic agents was due to the perseverance of Paul Ehrlich, who was awarded the Nobel Prize in 1908 [32-35].

Of all the compounds prepared before 1909, product No. 606 proved to be particularly effective against syphilis. It was marketed as Salvarsan ${ }^{\circledR}$ in Europe, and was known as Arsphenamine in the USA. It was originally thought that this compound was an arsenic analog of azobenzene; it was represented as 1, a dimer with an $-\mathrm{As}=\mathrm{As}$ - double bond and designated as 3,3'-diamino-4,4'-dihydroxyarsenobenzene (Scheme 1.4).<smiles>Nc1cc(C=[As]=[As]c2ccc(O)c(N)c2)ccc1O</smiles>

1<smiles></smiles>

4

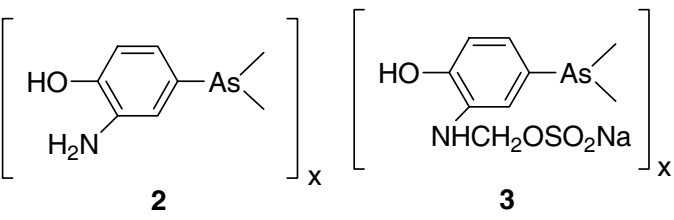<smiles>Nc1nc(N)nc(Nc2ccc([As]3SCC(CO)S3)cc2)n1</smiles>

Scheme 1.4 Chemical structure of Salvarsan 2, NeoSalvarsan 3, Mapharsen 4 and Melarsoprol 5. 
6 6 1 A Novel Field of Research: Bioorganometallic Chemistry, Origins, and Founding Principles

Subsequent studies have shown that unsubstituted arsenobenzene is in fact a cyclic hexamer $\left[\left(\mathrm{C}_{6} \mathrm{H}_{5} \mathrm{As}\right)_{6}\right]$ and it seems probable that Salvarsan 2, is also polynuclear (Scheme 1.4) [30]. The 200DM banknote included an image of the structure in this configuration. Although Mapharsen ${ }^{\circledR}, 4$, is conventionally represented as an As(III) species with a double bond to oxygen (analogous to a nitroso-arene), this presumably cannot be correct and it is more likely to be an arsenious acid or a related cyclic structure. Unfortunately, X-ray crystallographic data do not appear to be available but the composition of Salvarsan has now been shown by mass spectroscopy (N. C. Lloyd, H. W. Morgan, B. K. Nicholson, R. S. Ronimus, Angew. Chem. Int. Ed. 2005, 44, 941-944).

Salvarsan rapidly became the drug of choice for the treatment of syphilis, whose ravages at that time may be compared to those of AIDS today. Salvarsan itself is not easily soluble in water and its hydrochloride form proved too toxic for medical use. Salvarsan was therefore dissolved in a basic solution and administered in that form [34]. Some time later, NeoSalvarsan ${ }^{\circledR}$ (No. 914; neoarsphenamine 3), a water-soluble derivative, resolved this difficulty [34]. However, both Salvarsan and NeoSalvarsan oxidize in air, and must be stored in sealed ampoules under a nitrogen atmosphere.

1.2 .3

Arsenic Compounds after Ehrlich

After the death of Ehrlich in 1915, research into the organoarsenicals continued, and it was discovered that, in the body, Salvarsan was oxidized to oxophenarsine hydrochloride 4 (marketed as Mapharsen ${ }^{\circledR}$ ). Since this compound was stable in air, it gradually replaced Salvarsan for therapeutic use, to the point where it became the predominant organoarsenic medicine during the 1930s.

Mapharsen and other arsenic analogs remained in therapeutic use throughout the 1940s but were gradually replaced by penicillin. This does not mean that organoarsenic compounds have completely disappeared from the market. Indeed, they are still employed in veterinary medicine for their antiparasitic properties, and their antiviral activity has recently been studied.

There remain a number of open questions concerning Salvarsan and its relatives, not least its actual structure and its mode of action. H. Morgan of the University of Waikate has developed a research program into the treatment of antibioticresistant infectious agents, based on the work of Ehrlich. Certain bacteria, including some that cause gastroenteritis, syphilis, intra-uterine infection and lyme disease, share the ability to break down sugar using a unique enzyme, but this enzyme may be blocked by using compounds containing arsenic. It would thus be interesting to discover whether Salvarsan or other related molecules might be able to block this key enzyme. Another compound worthy of note is Melarsoprol 5 (Arsobal ${ }^{\circledR}$ ), used in the treatment of African sleeping sickness [36, 37], while this and other compounds in the same series are effective in the treatment of refractory acute leukemia [38-40]. 


\subsection{4}

\section{Organometallic Mercury Compounds}

Mercury has been used in medicine since the time of Ancient Greeks, according to the account of Diascorides, and it is described by Avicenna in the early Middle Ages (980-1037) as a treatment for lice and scabies. Even in those times, the longterm toxicity of mercury was known [41], to the extent that the life expectancy of criminals used in the cinnabar mines of Spain by the Romans was as little as 3 years. The ideas of Paracelsus (1493-1541) expressed during his tenure at the University of Basel, are often quoted on the subject of the nature of toxicity: Paracelsus wrote, "Alle Ding sind Gift und nichts ohn Gift; alein die Dosis macht das ein Ding kein Gift ist [All things are poison and not without poison; only the dose makes a thing not a poison]. For example, all food and all drink is a poison if consumed in quantities beyond the normal usage." [41, 42]. On this basis, he recommended the use of inorganic metal complexes for medical purposes, including compounds of arsenic and mercury. These compounds played a role in the treatment of syphilis for several centuries: see for example, J. J. Casanova de Seingalt (1725-1798) "Histoire de ma vie" (My life story). There is an interesting historical parallel between the compounds of mercury and those of arsenic, both in terms of the gradual change in approach from inorganic to organometallic chemistry, and the use of the resulting compounds 6 and 7 as medications (Scheme 1.5) or, in the case of the mercury or arsenic alkyls, as large-scale toxins [43].<smiles>O=C1C=C2Oc3c(cc(Br)c(O[O-])c3O)C2(c2ccccc2C(=O)[O-])C=C1Br</smiles>

6<smiles>CCOSc1ccccc1C(=O)O[Na]</smiles>

7

Scheme 1.5 Chemical structure of mercurochrome 6 and merthiolate 7.

Organomercury compounds are considered of little therapeutic interest today, although mercurochrome and merthiolate are still used as mild local antiseptics. This underlines the common tendency for compounds of this type; they are normally prescribed as external antibiotics rather than for internal use. In fact most cases of organometallic poisonings are due to ingestion of methylmercury compounds either from marine organisms or from treated seed grain [44].

1.2 .5

The Current Re-evaluation: Considerations of Efficacy, Toxicity and Selectivity

In addition to the explosion in synthetic potential given to organometallic chemistry by the wide range of new functional groups discovered in the second half of the 
twentieth century (Scheme 1.1), the other founding event that relaunched the field of metal-based drugs is directly attributable to Rosenberg. He discovered the antitumoral effects of the inorganic drug cisplatin, 8, in particular against testicular cancer. The compound had been synthesized in 1844 by Peyrone [45] but it was not until 120 years later that Rosenberg revealed its properties [46, 47].

To date, around 20000 articles on platinum complexes have been published; an excellent approach to the subject can be found in the book by Lippert [48], and overviews of metal antitumor agents can be found in the publications of Keppler [49], Sadler [50] or Clarke [51]. Despite this huge volume of work, the only inorganic complexes approved for clinical use as antitumor drugs are cisplatin, 8, carboplatin, 9, nedaplatin, 10, and oxaliplatin, 11 (colorectal cancer) (Scheme 1.6). Several others are in clinical testing, and the mechanism of action has been examined [52].<smiles>N[PH](N)(Cl)Cl</smiles>

8<smiles>N[PH]1(N)OC(=O)C2(CCC2)C(=O)O1</smiles>

9<smiles>N[PH]1(N)OC(=O)C(=O)O1</smiles>

10<smiles>NC1(N)OC(=O)C(=O)O1</smiles>

11

Scheme 1.6 Chemical structure of cisplatin 8, carboplatin 9, nedaplatin 10, oxaliplatin 11.

The impetus to search for anticancer complexes other than those of platinum stems from its various drawbacks, including cellular resistance to platinum which is sometimes encountered in the clinic; the toxic side effects of cisplatin 8 , which can be severe; and its limited spectrum of activity against other types of cancer [48]. In an attempt to overcome these difficulties, in particular those linked to general toxicity, the possibility of using inorganic complexes of other metals has been explored. For this purpose, complexes of ruthenium, a metal with properties similar to the naturally present element iron, seem particularly attractive. For example, a ruthenium(III) salt, 12 (NAMI-A), [ImH $]^{+}\left[\text {trans- } \mathrm{RuCl}_{4}(\mathrm{dmso}) \mathrm{Im}\right]^{-}$, imidazolium trans-imidazole(dimethylsulfoxide)tetrachlororuthenate (Scheme 1.7), shows interesting antimetastatic activity as well as possessing low toxicity in vivo $[53,54]$. Phase I clinical trials indicate that it is well tolerated in human subjects [55].

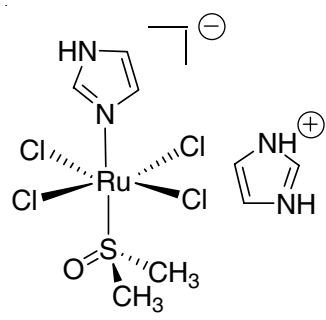

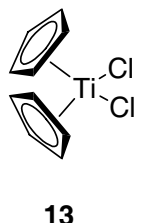

12

Scheme 1.7 Chemical structure of NAMI-A 12, and titanocene dichloride 13. 
In parallel with the studies being carried out in coordination chemistry, organometallic complexes of the same type have also been the subject of considerable endeavor, particularly those in the metallocene series with metals such as Ti, Fe, Mo, V, Re, Co, Ru, [56-59]. Titanocene dichloride, 13, is paradigmatic; the structural analogy between 13 and cisplatin 8 is immediately clear. This organometallic complex 13 has been in clinical trials and was believed to react with DNA in a similar manner to cisplatin. However this complex is difficult to formulate for administration because of its ready hydrolysis. The clinical response was not encouraging and trials have been abandoned. It should also be noted that the $\mathrm{Ti}(\mathrm{IV})$ products resulting from the hydrolysis process show a strong proliferative effect in hormone-dependent breast cancers [60]. The research continues, however, using titanium complexes of particularly robust ligands $[61$, 62]. A concurrent approach, with the aim of lowering the toxicity of these metallic drugs, is based on changing the central metal. The organometallic complexes of $\mathrm{Ru}$ are confirming their promising early results for this purpose. In particular, half-sandwich complexes, such as the ( $\eta^{6}$-arene) Ru(II) systems 14 and 15 shown in Scheme 1.8, show only low general toxicity $[63,64]$.

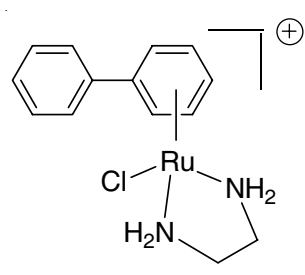

14

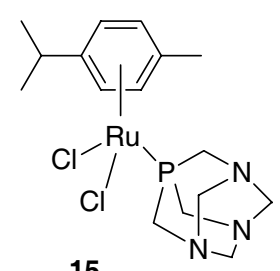

15

Scheme 1.8 Organometallic complexes of ruthenium 14 and 15.

Complex 14 shows promising anticancer activity both in vitro and in vivo, including activity against cisplatin-resistant cell lines [63]. Such organometallic complexes offer much scope for optimization of biological activity by changing the coordinated arene, the chelated ligand, and the chloride leaving group. Molecule 15 shows antimicrobial properties and $\mathrm{pH}$-dependent binding properties [65]. These results are discussed in Chapter 2.

The approach described below is different and promising: it is based on modification via organometallic chemistry of a known bioligand (tamoxifen, chloroquine) in such a way as to optimize its effects. This selective targeting aims to increase efficacy via the organometallic functionality, perhaps involving the formation of oxidized species proximate to the active site [66-73].

Scheme 1.9 summarizes two approaches that are most developed to date, to illustrate the targeting principle. The SERMs (Selective Estrogen Receptor Modulators), of which tamoxifen 16 (active metabolite hydroxytamoxifen, OHTam, 17) is the prototype, represented a significant step forward in the treatment of hormone-dependent breast cancer (ER+). To address the problem of nonhormone-dependent (ER-) tumors, hydroxyferrocifen (OH-ferrocifen, 18) was 

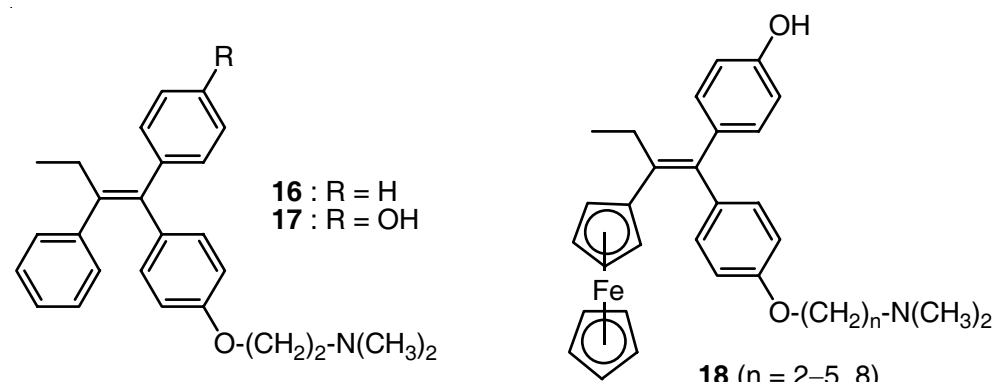

Scheme 1.9 The antiestrogen tamoxifen 16, its active metabolite hydroxy tamoxifen 17 and hydroxy ferrocifens 18.

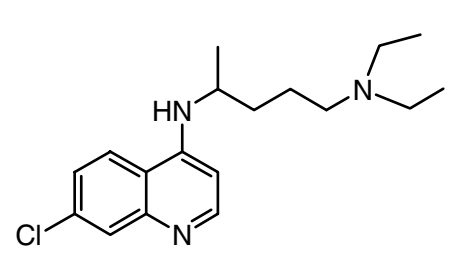

19<smiles></smiles>

20

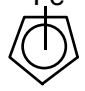

Scheme 1.10 Chemical structure of chloroquine 19 and ferroquine 20.

prepared. This molecule shows antiproliferative effects on breast cancer cells classed either ER(+) or ER(-). This is due to the particular properties of ferrocifen in an oxidizing environment, which in this type of structure produces targeted apoptosis [67-69].

The other current example involves malaria. Chloroquine, 19, one of the currently prescribed antimalarials, is subject to resistance phenomena, while ferroquine 20, surprisingly, does not have this problem. The latter product is currently in clinical development at Sanofi-Aventis [73]. All of these recent developments are discussed in detail, with further examples, in Chapter 3.

1.3

Toxicology and the Environment

This book will not deal in detail with the toxicological and environmental problems associated with the use of organometallics since these subjects have been covered extensively in books by Thayer [44] and Craig [74], respectively. However, it is worth noting that the toxicity of organometallic compounds, e.g. $\mathrm{Ni}(\mathrm{CO})_{4}$, was recognized almost as soon as they were discovered. For the record, and as an illustration, a few historical incidents are briefly outlined here. 
Minamata disease was the name given to organomercury poisoning following the first reported large-scale event of this type, to which the inhabitants of the Minamata Bay area in Japan fell victim in 1953. The toxin was $\mathrm{CH}_{3}-\mathrm{Hg}-\mathrm{SCH}_{3}$ [75], from the shellfish Hormonya mutabilis, but downstream of the effluents of a factory preparing acetaldehyde [76]. Owing to these serious toxicological problems, the biology of methyl mercuric chloride is the most intensely studied of all organometallics [44].

Organoarsenics were considered for use in poison gas attacks during the First World War. The best known of these gases is lewisite $\left(\mathrm{ClCH}=\mathrm{CHAsCl}{ }_{2}\right)$, which was proposed as a "blistering gas" but was never used [77]. Poison gas research led to the development of antidotes, of which the most widely used was 2,3-dimercaptopropanol $\left[\mathrm{HSCH}_{2} \mathrm{CH}(\mathrm{SH})-\mathrm{CH}_{2} \mathrm{OH}\right]$, known as mercaprol or BAL (British anti-lewisite). It works by binding to the arsenic atom to form a water-soluble complex that is excreted by the body [78, 79].

An early organometallic molecule, tetraethyl lead, which was first made in Zurich by Löwig [80], was widely used for a period of time as a fuel additive, until recognition of its effects on the environment and its implication in cases of environmental poisoning led to its prohibition [81]. The toxicology of ( $\eta^{5}$-methylcyclopentadienyl) manganese tricarbonyl (MMT) has also been studied; it is a permissible fuel additive in some jurisdictions in North America.

The unfortunate story of "Stalinon" was very harmful to the biological development of tin-based organometallic compounds. Like Minamata disease, it severely delayed the development of therapeutic applications for organometallics. In 1954, 4 million capsules, prepared for the treatment of staphylococcal infections and believed to contain diethyltin diiodide, were distributed in France under the name of "Stalinon". This was a case of the cure being worse than the disease; 102 people died and as many were affected by various neurological disorders. It was subsequently shown that $\left(\mathrm{C}_{2} \mathrm{H}_{5}\right)_{2} \mathrm{SnI}_{2}$, and even more so $\left(\mathrm{C}_{2} \mathrm{H}_{5}\right)_{3} \mathrm{SnI}$ (present as an impurity), were powerful neurotoxic agents $[82,83]$.

This reputation for toxicity clearly has not been advantageous for the development of therapeutic applications for organometallic compounds, although a more favorable tendency is in evidence for the derivatives of silicon, phosphorus or germanium [84-86]. It should be noted, however, that although attaching organic groups directly to the metal may increase toxicity, this is not always the case. It was noted earlier that organic compounds of arsenic are less toxic than their inorganic analogs and that this observation led to Ehrlich's pioneering work on chemotherapy.

We cannot conclude this brief historical outline of organometallics without mentioning Gosio gas. Starting in nineteenth-century Germany, cases were reported of poisoning occurring in rooms decorated with wallpaper that had been colored using arsenate salts. In dark, poorly ventilated, damp and musty conditions, the paper could be attacked to give off a volatile, evil-smelling compound that contained arsenic. Gosio proposed that this toxic compound was $\left[\left(\mathrm{C}_{2} \mathrm{H}_{5}\right)_{2} \mathrm{AsH}\right]$ [87]. But it was in fact Challenger who solved the problem [88, 89], identifying the gas as containing $\left[\left(\mathrm{CH}_{3}\right)_{3} \mathrm{As}\right]$, trimethylarsine, and realized that it was caused by a 
biological process involving molds with $S$-adenosylmethionine, and coined the term "biological methylation" to describe this process which turned out to be a more general one. Such biological methylation processes to give toxic organometallics may also involve methylcobalamine. The same question has arisen for $\mathrm{Hg}$ and $\mathrm{Sn}$, in the latter case concerning the organotins used as antifouling agents.

1.4

Bioanalytical Methods Based on Special Properties of Organometallic Complexes

The development of the radioimmunoassay (RIA), an indirect assay method using radioactive tracers and specific antibodies of the analyte, made great strides in the 1960s, following the work of Yalow and Berson [90, 91]. This development was decisive in the history of bioanalysis, since it increased assay sensitivity by a factor of at least 1000 compared to direct assay [92]. The possibility of using organometallics in this context was first raised by Gill and Mann [93]. These authors were interested in the possibility of labeling a ferrocene with ${ }^{59} \mathrm{Fe}$, a radioactive isotope of iron, which is a mixed $\beta$ and $\gamma$ emitter with a half-life of 44.5 days. Injection of a synthetic polypeptide labeled with 2 or 16 ferrocene entities into rabbits produced anti-ferrocene specific antibodies, incidentally establishing the non-toxicity and stability of ferrocene in vivo. It was soon realized however that the use of radioisotopes was not without problems, including their limited shelf life, the relatively small number of usable isotopes, and cost. But it was the associated health risks that brought about draconian controls and led to their use being limited to a few specialized analytical laboratories. The early 1970s consequently witnessed the appearance of the non-isotopic approach, that is, the development of immunological tests not requiring the use of radioactive tracers. Of these, methods using enzymatic, fluorescent or luminescent probes received particular attention $[94,95]$. The potential offered by metal probes, whether the metals were in the form of gold colloids, rare earth chelates with interesting fluorescence properties, or organometallic complexes, quickly became apparent [96-98]. Cais in particular introduced the term metallo immuno assay (MIA) as early as 1977 to refer to immunoassays using metal complexes as tracers [96]. Some of these in fact possess unusual physico-chemical properties that allow them to be analyzed in the picomole range, as required by immunoassay. In addition, the great versatility of organometallic synthesis permits relatively straightforward access to tracers corresponding to a large number of desired analytes (cf. Table 8.1). Since Chapter 8 provides a complete review of this subject, just a few examples of the pioneering work done in this field should suffice here.

The mid-1980s saw the development of the first three non-isotopic immunoassays to use organometallic tracers that actually came to fruition. They are based on three different analytical techniques: atomic absorption, electrochemistry, and Fourier-transform infrared spectrocopy (FT-IR) [99-101]. Cais himself did not bring to completion an actual immunoassay by atomic absorption, although he tested the technique with this view in mind [102]. Brossier was the first to validate 


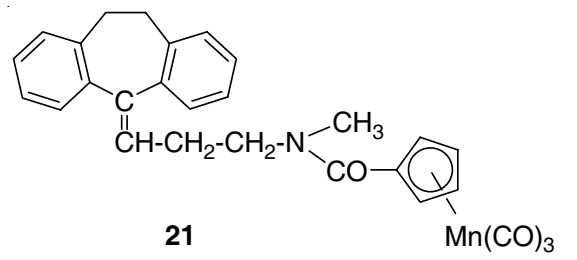<smiles></smiles>
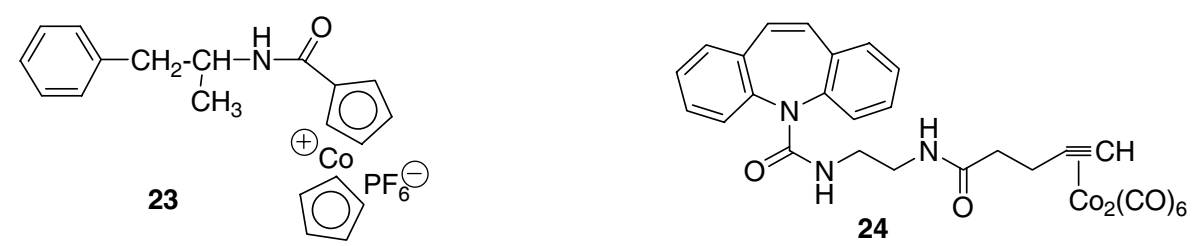

Scheme 1.11 Representative organometallic tracers used in metalloimmunoassays.

21 (cymantrenyl tracer of the nortryptiline),

22 (ferrocenyl tracer of lidocaine),

23 (cobaltocenium tracer of amphetamine),

24 (alkyne dicobalt hexacarbonyl tracer of carbamazepine).

this approach, in the case of antidepressants [103] by quantifying the manganese atom in the nortryptiline tracer 21 . This technique suffers, however, from a lack of sensitivity because of possible solvent contamination by trace metals, and has not been the subject of recent development.

Electrochemical analytical methods all possess high sensitivity, require only low-cost (and miniaturizable) instrumentation, and can be used in turbid conditions. In addition, the unusual electrochemical behavior of ferrocene, which possesses a reversible and stable redox response, was quickly recognized. McNeil accordingly published as early as 1986 an ingenious homogeneous ferrocenemediated amperometric immunoassay of lidocaine, a drug used in the treatment of cardiac arrhythmias, by using the ferrocenyl tracer of lidocaine 22 [100]. Later, Degrand and Limoges developed another type of immunoassay based on electrochemical detection of the electroactive cationic cobaltocenium derivative of amphetamine 23 combined with the specific properties of Nafion ${ }^{\circledR}$ [104]. Electrochemical detection is also the basis of DNA sensors or genosensors, a new family of biosensors for the detection of pathogens or specific genes associated with diseases (see Chapter 9). It is interesting to note that a biosensor of this type, the eSensor ${ }^{\mathrm{TM}}$, developed by Farkas [105-107] has reached the market. The principle of its activity is shown in Fig. 1.1.

Another commercially successful product is the "ExacTech Pen", manufactured by Medisense Inc., which is used to monitor glucose levels in people with diabetes. Glucose oxidase (GOD) is immobilized onto a pyrolitic graphite electrode, and the ferrocenyl center in $\mathbf{2 5}$ (Scheme 1.12) is used to shuttle electrons between the enzyme and the electrode. The ferricinium ion replaces oxygen as the cofactor for GOD. The formal potential of the ferrocene depends on the substituents on one or both rings, but the electron transfer reaction retains the advantageous qualities of rapidity and reversibility [100]. 


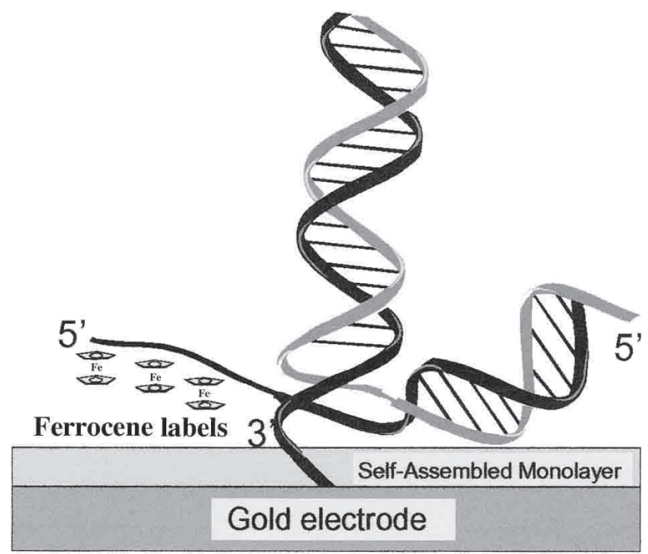

Fig. 1.1 Schematic representation of the eSensor ${ }^{\mathrm{TM}}$ DNA Detection System. A self-assembled monolayer is generated on a gold electrode. For electrochemical detection to occur across the monolayer, two hybridization events must occur: the first between the capture probe (shown in black perpendicular to the electrode) and the target (for example, human papillomavirus DNA, shown in gray), and the second between an adjacent region of the target and ferrocene labeled signal probe (shown in black parallel to the monolayer) [106].

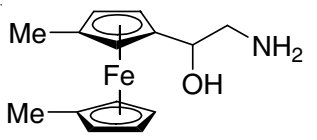

25

Scheme 1.12 Ferrocene complex used to monitor glucose in blood.

The third technique, infrared spectroscopy, was revolutionized at the beginning of the 1980s, when the old dispersive equipment was replaced by Fourier-transform instruments served by desktop computers. It was this technological revolution that permitted the development of infrared spectroscopy as a reliable and sensitive analytical technique $[108,109]$. Metal carbonyls with an M-CO bond are one of the major families of organometallic compounds (see Scheme 1.1), at the basis of the first organometallic industrial applications (Mond, Roelen) as well as recently put to new uses (Fischer carbenes), but they are also well-known for their unique spectroscopic properties in infrared (see Chapter 7). In fact the very intense stretching vibrations of $\mathrm{M}-\mathrm{CO}$ bonds resonate in infrared in the $2000 \mathrm{~cm}^{-1}$ region, a zone where practically no standard organic functions resonate at all. This is clearly visible in the spectrum of the chromium carbonyl complex, 26, whereby the characteristic $\mathrm{a}_{1}$ and e $v_{\mathrm{CO}}$ stretching vibrations, typical of a $C_{3 \mathrm{v}}$ symmetric moiety, appear at 1956 and $1876 \mathrm{~cm}^{-1}$ (Fig. 1.2). These bands are also 8-10 times more intense than any other band in the spectrum and appear in an absorption window for proteins (Fig. 1.3). 


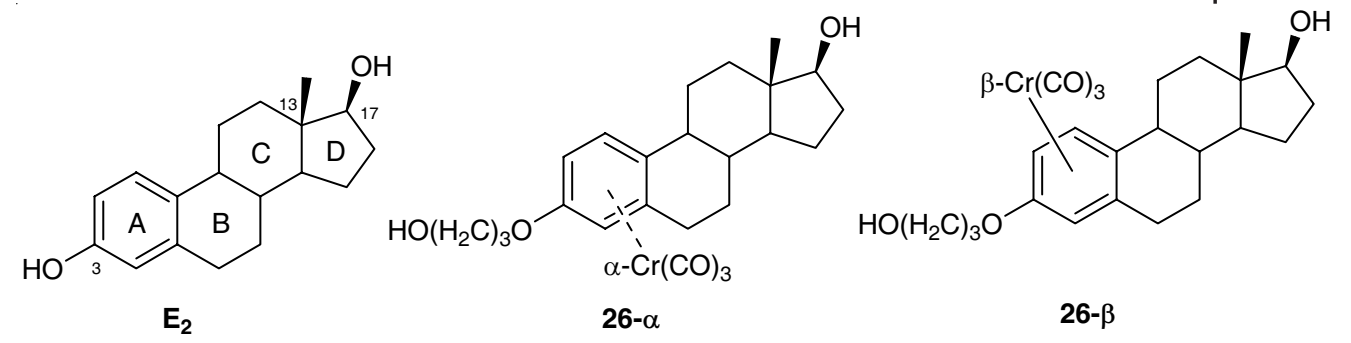

Scheme $1.1317 \beta$-estradiol $\left(E_{2}\right)$ and the $\alpha$ and $\beta$ benchrotrenyl complexes $26 \alpha$ and $26 \beta$ of an estradiol derivative [110].

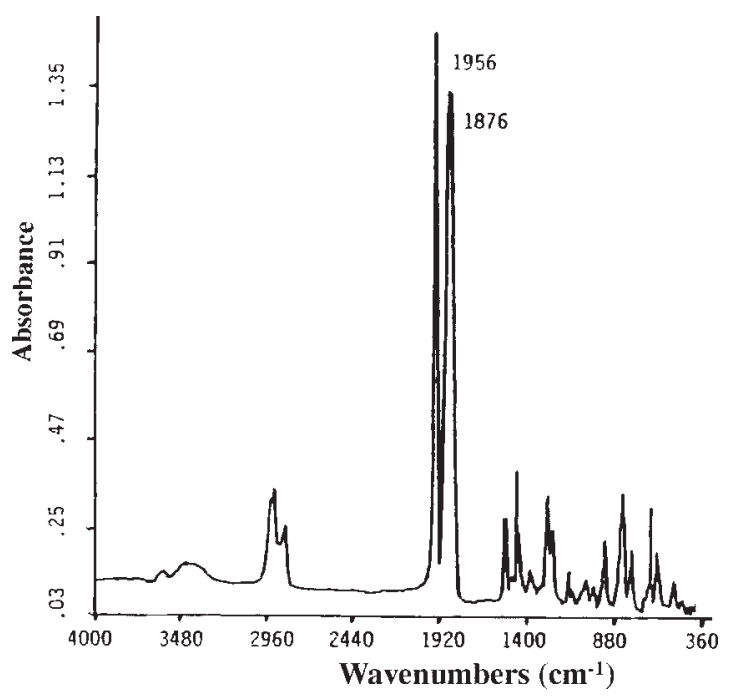

Fig. 1.2 FT-IR spectrum of $26 \alpha$ in CsI mini pellet [111].

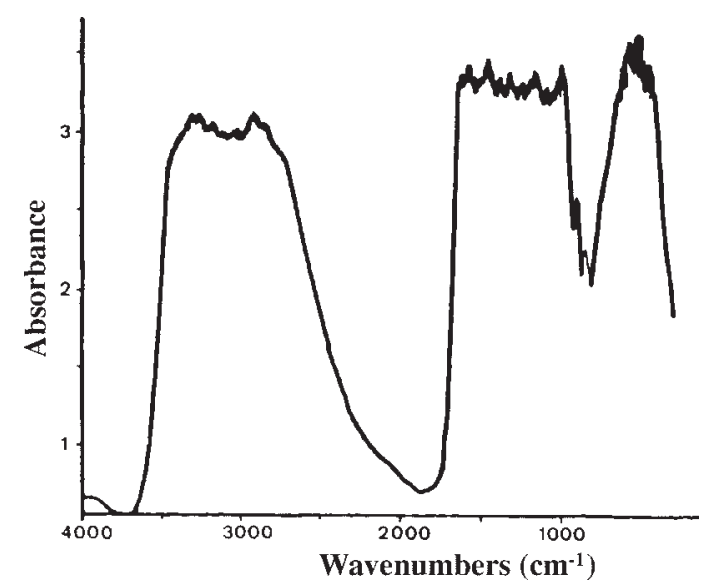

Fig. 1.3 FT-IR spectrum of a mini pellet of lyophilized proteins (from uterine cytosol), off scale, MCT detector [1]. 


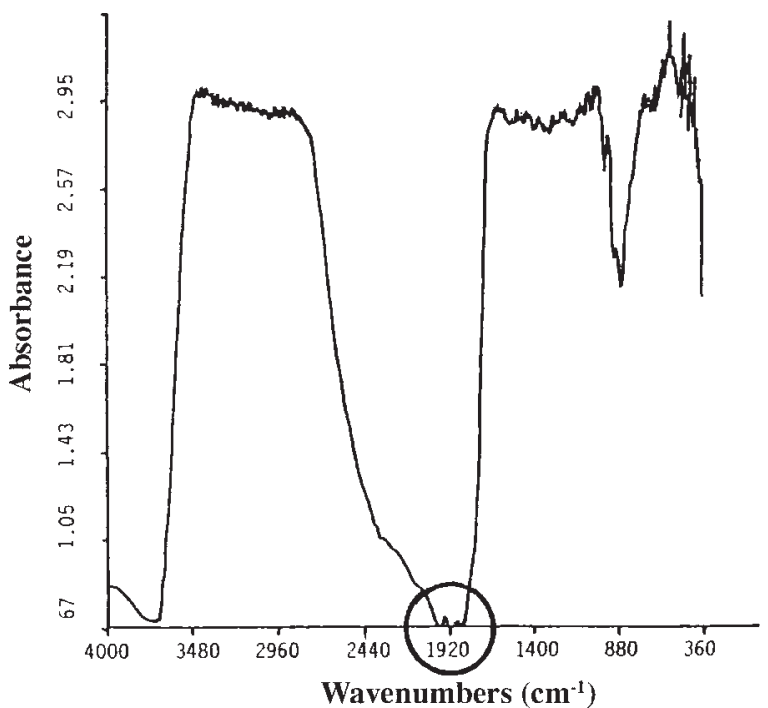

Fig. 1.4 FT-IR spectrum of lamb uterine cytosol following incubation with $26 \alpha$ and subsequent precipitation from solution with protamine sulfate (off scale, MCT detector) [111].

This unusual property, and in particular its analytical potential, was demonstrated for the first time in 1985 in the case of a hormone bound to its specific receptor $[1,2,111]$. The initial idea was to complex the aromatic A ring of estradiol with a $\mathrm{Cr}(\mathrm{CO})_{3}$ entity (Scheme 1.13). The corresponding complex was successfully prepared, but the presence of a phenol entity makes it unstable and thus unusable in biological media. Moreover, it is well known that this phenol group is essential for the interaction of the hormone with its receptor. Distancing the $\mathrm{OH}$ group using a 3 -carbon chain produced two stable diastereoisomers, $26 \alpha$ and $\beta$, with the $\mathrm{Cr}(\mathrm{CO})_{3}$ moiety on either one face of the steroid or the other. The $\beta$ isomer, the one in which the $\mathrm{Cr}(\mathrm{CO})_{3}$ group is on the same side as the $17 \beta-\mathrm{OH}$ and $13 \beta-\mathrm{CH}_{3}$ groups, shows only weak recognition for the estrogen receptor $(\mathrm{RBA}=1.8 \%)$ while recognition of the $\alpha$ complex is much better $(\mathrm{RBA}=28 \%$ ). To date, it is still the only example in the literature that is capable of discrimination, at the level of the A ring, between the $\alpha$ and $\beta$ faces of estradiol.

Although the amounts of estradiol receptor in target tissues (uterus, certain hormone-dependent breast tumors) are small (in the fmol $\mathrm{mg}^{-1}$ protein range), it was possible to detect the characteristic bands in FT-IR of the organometallic hormone $26 \alpha$ bound to the estrogen receptor and contained in a precipitated cytosol from sheep uterus (Figs. 1.4 and 1.5).

It was difficult to envisage a solid-phase quantitative analysis at this level of concentration. However, for an alkyne cobalt hexacarbonyl complex such as 24 in a chlorinated solvent, use of an ultralow volume gold light-pipe can provide a detection limit as low as $300 \mathrm{fmol}$ (i.e $10 \mathrm{nM}$ ), [108], a level fully compatible with the sensitivity range required for the assay of many medications and banned drugs. 


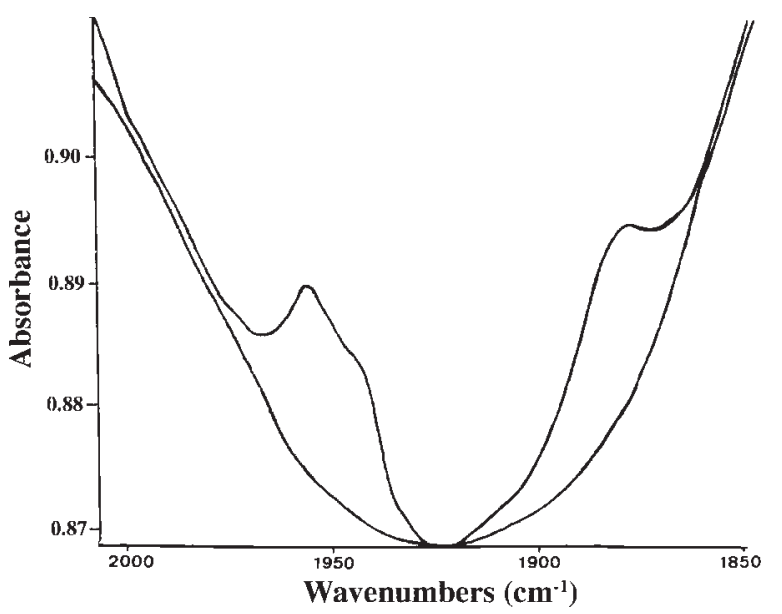

Fig. 1.5 FT-IR spectrum of the metal carbonyl area of lamb uterine cytosol incubated with (a) $10 \mathrm{nM}$ of $\mathbf{2 6} \alpha$ and (b) $10 \mathrm{nM}$ of $\mathbf{2 6} \alpha$ plus a 500 -fold excess of the estrogen diethylstilbestrol (26 000 scans, InSb detector) [110].

This possibility led to the development of the CMIA method to assay antiepileptic medications [101, 112-114] and cortisol [115], a method that offers the additional potential of the simultaneous triple immunoassay, thanks to the distinct and nonoverlapping infrared bands of carefully-selected metal carbonyl probes [116]. It is also possible to displace the $v_{\mathrm{CO}}$ bands in the infrared by modifying the electron density at the metal, via substitutions of $\mathrm{L}$ or $\mathrm{Cp}$ ligands [117]. In addition, solvation and environmental phenomena can cause the $v_{\mathrm{CO}}$ vibrations to shift. The harnessing of these phenomena is described in Chapter 7.

\section{5}

\section{Naturally-occurring Organometallics and Synthetic Models}

The relationship between organometallics and Nature is very old, and the last few decades have revealed in it new levels of complexity.

It is now accepted that this planet was formed 4.6 billion years ago. The oldest sedimentary rocks containing carbon of biological origin (which can be distinguished by its slightly different isotopic composition) were recently discovered on the island of Akilia, to the south-west of Greenland. These rocks have been shown to be 3.85 billion years old [118].This means that living organisms, presumably very rudimentary and obviously microscopic, must have appeared very quickly on a planet still being bombarded by ultraviolet radiation and with no atmospheric oxygen. The simple molecules present on the earth at that time included $\mathrm{H}_{2}, \mathrm{CH}_{4}, \mathrm{H}_{2} \mathrm{O}, \mathrm{H}_{2} \mathrm{~S}, \mathrm{~N}_{2}, \mathrm{NH}_{3}, \mathrm{HCN}, \mathrm{CO}, \mathrm{CO}_{2}$. The overall result was a reducing atmosphere very suitable for organometallic chemistry [119]. The question of how the first spark of life arose remains unanswered, but it is 
conceivable that the bridge between the inorganic and biological worlds, via the effect of metal clusters of the Fe-S type, could have involved the intervention of organometallics [120]. The known capability of FeS and NiS species to catalyze the synthesis of acetyl methyl sulfide from CO and methyl sulfide constituents of hydrothermal fluids, indicates that prebiotic syntheses could have occurred at the interface of these metal-sulfide walled compartments, providing sufficient concentrations of reactants to forge the transition from geochemistry to biochemistry [121].

Little by little, research into carbon-metal bonds in natural systems became established $[23,122]$. Historical primacy belongs to vitamin $\mathrm{B}_{12}$, its coenzyme and methylcobalamin $[16,123,124]$ which were long considered the only naturallyoccurring compounds with a metal-carbon bond. The story begins with the observation that raw liver is a cure for an otherwise fatal condition, pernicious anemia. The active component extracted from the liver was first separated and then crystallized in 1948. Dorothy Hodgkin made the first crystallographic structural determination in the series, that of cyanocobalamin, with a tetrapyrrole ligand of the corrin type occupying the horizontal plane. Depending on the example, one of the axial sites may be occupied by a carbon ligand (methyl for methylcobalamin, adenosyl for the coenzyme of vitamin $\mathrm{B}_{12}$ ) (Scheme 1.14).

The elucidation of the structure of vitamin $B_{12}$ was a tour de force of the early days of X-ray diffraction and was recognized in 1964 by the award of the Nobel Prize to Dorothy Hodgkin. The coenzyme $\mathrm{B}_{12}$ acts in concert with a variety of enzymes that catalyze reactions of three main groups. In the first, two substituents on adjacent carbon atoms, $-\mathrm{X}$ and $-\mathrm{H}$, are permuted, this is called the isomerase reaction. In the second type, methylcobalamin methylates a substrate, as in the conversion of homocysteine to methionine, for example. Finally, $\mathrm{B}_{12}$ is also involved

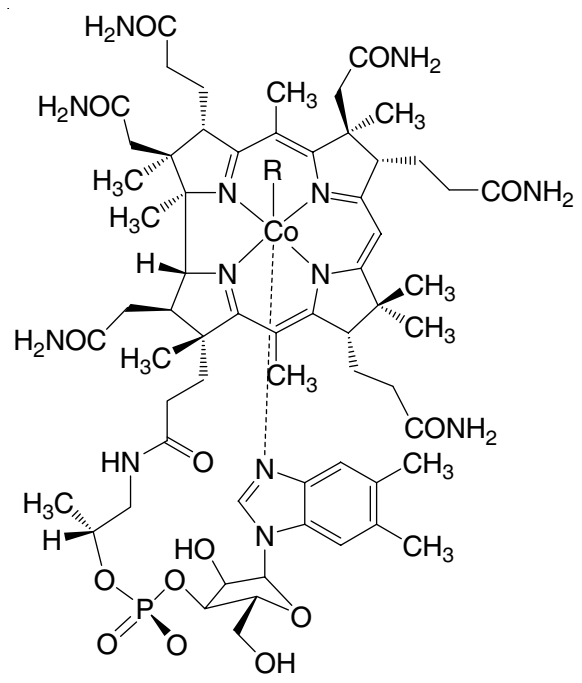
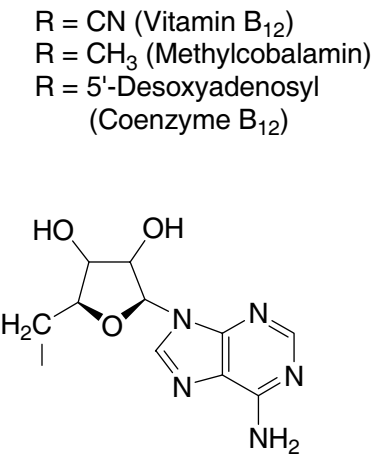

5'-Desoxyadenosyl (- $\left.\mathrm{CH}_{2} \mathrm{Ad}\right)$

Scheme 1.14 Vitamin $B_{12}$, methylcobalamin and coenzyme $B_{12}$. 
in the conversion of the ribose ring to the deoxyribose ring related to nucleotides. The coenzyme is required only in small amounts; $2-5 \mathrm{mg}$ is present in the average human, for example, and one of the first signs of deficiency is the failure to form red blood cells.

The role of the coenzyme $\mathrm{B}_{12}$ with a reducible cobalt(III)-alkyl bond which can function as nature's Grignard reagent $\left(\mathrm{CR}_{3}^{-}\right.$source), Meerwein's reagent $\left(\mathrm{CR}_{3}^{+}\right.$ source) or as radical source $\left(\mathrm{CR}_{3}^{*}\right)$ - the latter in the important 1,2-rearrangements e.g. of glutamic acid - is one of the most well studied fields in bioinorganic chemistry (Scheme 1.15). This area therefore will not be covered in this book.

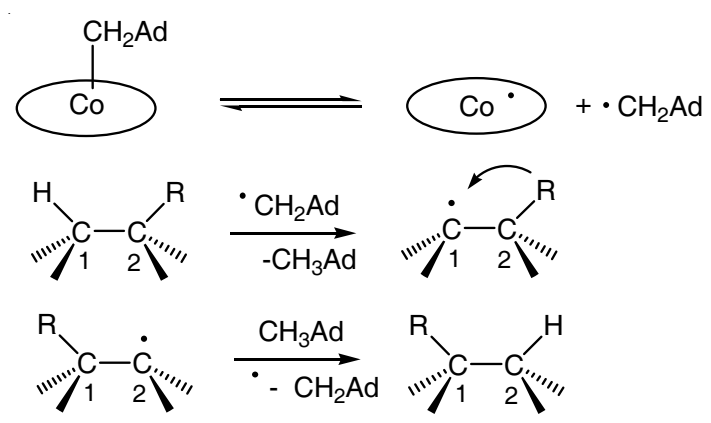

Scheme 1.15 Coenzyme $B_{12}$ catalyzes 1-2 rearrangement.

Many models for vitamin $B_{12}$, e.g. Schrauzer's cobaloximes [125], have been developed. Methylcobalamin is the agent for the methylation of metals e.g. to $\left[\mathrm{H}_{3} \mathrm{C}-\mathrm{Hg}\right]^{+}$(Scheme 1.16). It is interesting to note that bacteria (mercury lyases) can cleave the mercury carbon bond. This type of cleavage together with the reduction of organometallic compounds by biocatalysts has been reviewed by Ryabov [13].

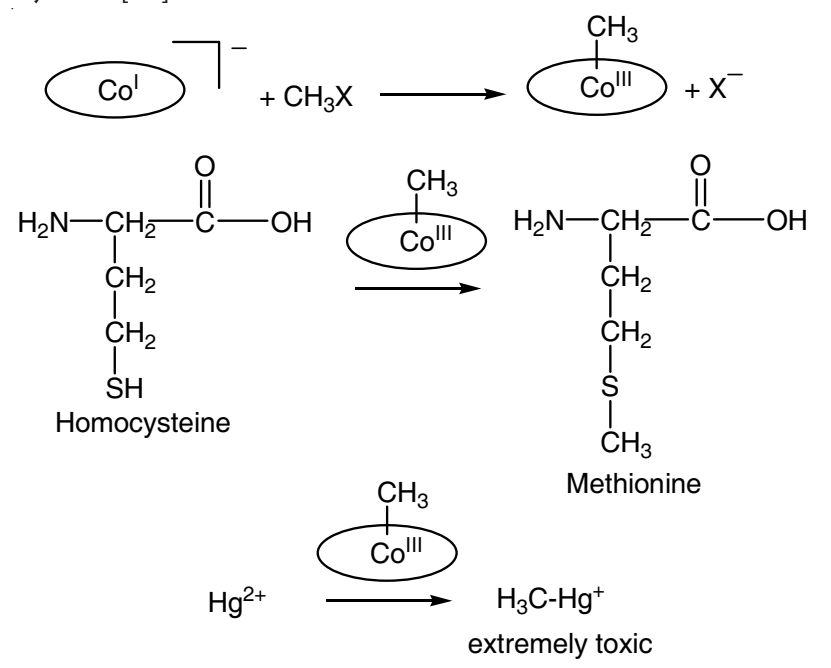

Scheme 1.16 Biomethylation with methylcobalamin. 
Although the question of the $B_{12}$ coenzyme remains of current interest [126128], recent research has focused on other cofactors of metal enzymes, certain of which owe their suprising properties to an organometallic reactivity that is not yet understood. Structural methods have been one of the keys to the recent advances on this front. In particular one may cite the active sites of nitrogenase $[129,130]$, hydrogenase and CO dehydrogenase/acetyl-coezyme A synthase [131134]. In this book, J. Fontecilla-Camps, one of the leaders in this area, presents an overview of all the recent mechanistic advances (Chapter 11) while T. Rauchfuss and R. Linck focus on biologically-inspired organometallic models (Chapter 12). These two divisions are currently advancing in parallel, making good progress and feeding off each other.

Nitrogenase, because of its facility for producing $\mathrm{NH}_{3}$ in mild conditions (Eq. 1.2), was a long-standing challenge for organometallic chemists.

$\mathrm{N}_{2}+8 \mathrm{H}^{+}+8 \mathrm{e}^{-}+16 \mathrm{MgATP} \stackrel{\text { nitrogenase }}{\longrightarrow} 2 \mathrm{NH}_{3}+\mathrm{H}_{2}+16 \mathrm{MgADP}+16 \mathrm{Pi}$

The harsh conditions of the Haber process to produce $\mathrm{NH}_{3}$ with iron catalysts are well known. Besides this, nitrogen is a poor ligand for coordination of metals. The first recognized dinitrogen complex was $\left[\mathrm{Ru}\left(\mathrm{NH}_{3}\right)_{5}\left(\mathrm{~N}_{2}\right)\right]^{2+}$, by Allen and Senoff in Toronto, which dates only from the 1960s [135]. This synthetic challenge to activate molecular nitrogen by organometallic means was undertaken among others by the Russian group of Shilov, and also by Chatt and by Schrock [136140]. Despite structural determinations to a resolution of $1 \AA$ it is still not completely understood how the hydrogen is reduced by the nitrogenase nor even how it binds initially to the cofactor FeMo, although majority opinion leans towards the belief that the association and the reduction of the nitrogen occur on one of the faces of the $\mathrm{Fe}_{4} \mathrm{~S}_{4}$ cluster.

The hydrogenases are classed into two major families, those containing $\mathrm{Ni}-\mathrm{Fe}$ and those containing only iron, Fe-Fe. Those in the first category tend to be more implicated in the oxidation of hydrogen and those in the second in the production of $\mathrm{H}_{2}$. The latter aspect is interesting in the context of new sources of combustibles.

The chemical reaction employed produces the following result (Eq. 1.3).

$$
\mathrm{H}_{2} \rightleftharpoons 2 \mathrm{H}^{+}+2 \mathrm{e}^{-}
$$

This class of enzymes was described for the first time in 1931 by Stephenson and Stickland [141]. A major article published in 1995 reported the X-ray crystallographic structural determination $\mathrm{Ni}-\mathrm{Fe}-\mathrm{H}_{2}$ ase from Desulfovibrio gigas [142, 143]. Among the interesting examples of this type of structure are a heterobimetallic $\mathrm{Fe}-\mathrm{Ni}$ active site, the presence of $\mathrm{CO}$ and $\mathrm{CN}$ ligands on iron, and Fe-S clusters on one of the constituents of the dimer. The Fe-only hydrogenase is evolutionarily distinct from $\mathrm{Ni}-\mathrm{Fe}-\mathrm{H}_{2}$ ase but has some common structural features e.g. $\mathrm{CO}$ and CN ligands. The seminal structures of C. pasteurianum (Cp) [144] and Desulfovibrio desulfuricans [145-147] have increased the focus of work on molecular models. The question of the relevance of these remains open, but the situation is gradually 
1.5 Naturally-occurring Organometallics and Synthetic Models $\mid 21$

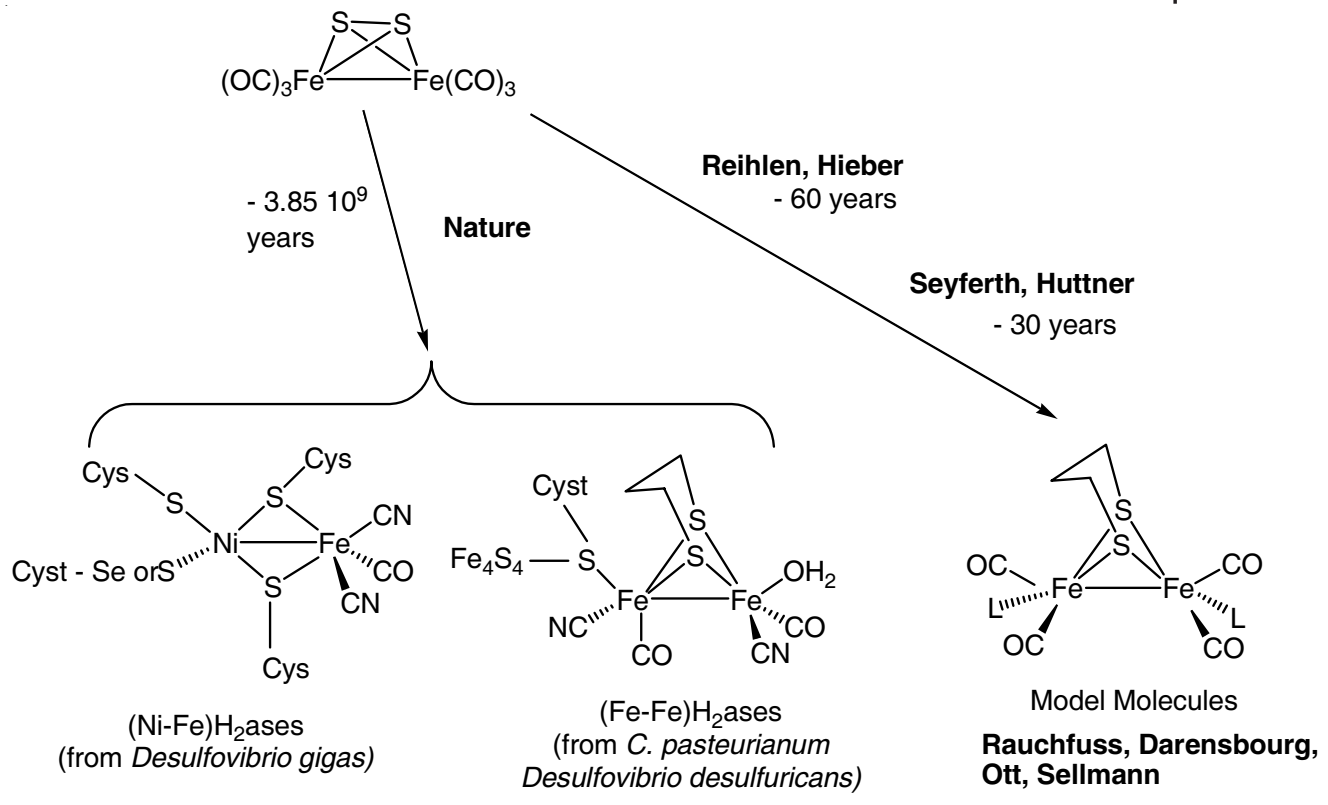

Scheme 1.17 Representation of the evolution of the CO-mobilized iron sulfide to yield the active sites of ( $\mathrm{Fe}-\mathrm{Fe}) \mathrm{H}_{2}$ ases and ( $\left.\mathrm{Ni}-\mathrm{Fe}\right) \mathrm{H}_{2}$ ases (adapted from [148]).

improving $[4,148-154]$. The parent complexes $(\mathrm{OC})_{3} \mathrm{Fe}(\mu \mathrm{SR})_{2} \mathrm{Fe}(\mathrm{CO})_{3}$ have a long and ongoing history [155-164] that began 75 years ago (Scheme 1.17).

The evolution of CO-mobilized iron sulfide in nature to yield the $[\mathrm{Fe}] \mathrm{H}_{2}$ ases can be compared to the biomimetic molecules synthesized in the last 60 years. It is true that the current intense interest in organometallic sulfur chemistry is largely based on a fascinating aspect of biology whose economic potential is just being realized [150]. A recent model molecule of $(\mathrm{Fe}-\mathrm{Fe}) \mathrm{H}_{2}$ ase is a real tour de force with a small $\mathrm{Fe}-\mathrm{Fe}$ cluster attached to a large $\mathrm{Fe}_{4} \mathrm{~S}_{4}$ cluster by a bridging cysteinyl unit [165]. We note that the reactions of organometallic enzymes in nature usually occur under anaerobic conditions, exactly as the organometallic chemist is accustomed to carrying out reactions with strict exclusion of oxygen.

The bacterial metalloenzyme acetyl coenzyme A synthase/CO dehydrogenase (ACS/CODH) catalyzes two very important biological processes, namely the reduction of atmospheric $\mathrm{CO}_{2}$ to $\mathrm{CO}$ and the synthesis of acetyl coenzyme A from $\mathrm{CO}$, a methyl from a methylated corrinoid iron-sulfur protein, and the thiol coenzyme A [166-168]. This bifunctional enzyme is the key to the Wood-Ljiungahl pathway of anaerobic $\mathrm{CO}_{2}$ fixation (Scheme 1.18) and a major component of the global carbon cycle. Reactions catalyzed by CODH and ACS are shown in Eqs. (1.4) and (1.5) below.

$$
\begin{aligned}
& \mathrm{CO}_{2}+2 \mathrm{H}^{+}+2 \mathrm{e}^{-} \stackrel{\mathrm{CODH}}{\rightleftharpoons} \mathrm{CO}+\mathrm{H}_{2} \mathrm{O} \\
& \mathrm{CO}+\mathrm{CH}_{3}-\mathrm{CFeSP}+\mathrm{CoA} \stackrel{\text { ACS }}{\rightleftharpoons} \text { acetyl-CoA }+\mathrm{CFeSP}
\end{aligned}
$$




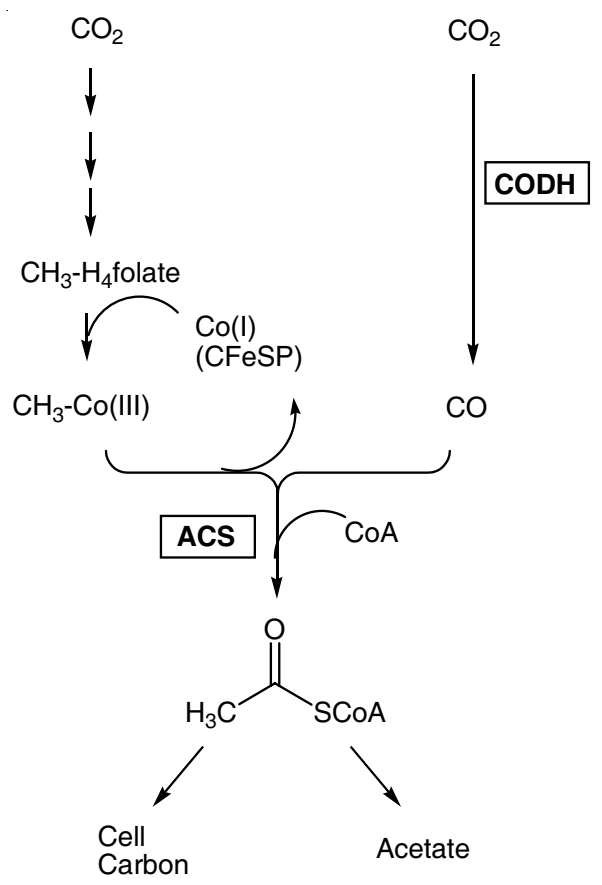

Scheme 1.18 Diagram of the Wood-Ljiungdahl pathway used in one-carbon metabolism of anaerobic organisms [167]. CODH stands for carbon monoxide dehydrogenase and ACS for acetyl-CoA synthase (adapted from [134]).

These reactions exhibit similarities to other well-known organometallic catalytic processes. Thauer, a pioneer in nickel enzymes, emphasized in his lectures the analogy between bioorganometallic chemistry in bacteria and the industrial Reppe and Monsanto processes for the production of acetic acid, both involving metalcarbonyl, metal-methyl, methyl-acetyl bonds [169]. In the Monsanto process carbonylation generates $\mathrm{CH}_{3} \mathrm{COI}$ which reacts rapidly with water to give $\mathrm{CH}_{3} \mathrm{CO}_{2} \mathrm{H}$. In the biological reaction, a thioester, also unstable in aqueous media, is easily hydrolyzed.

The nature of the active site of ACS has recently been the subject of much debate $[131,132,170,171]$. It has now been established that it contains two nickel atoms [131], although the mechanism is still under discussion [172]. For a review of the current situation, see Hegg [134, 173]. Still to be resolved issues are, inter alia, the order of introduction of $\mathrm{CO}$ and $\mathrm{CH}_{3}$, the mechanism of the $\mathrm{CH}_{3}$ migration, the nature of the electron reservoir, the oxidation state of $(\mathrm{Ni})$ (Scheme 1.19), and the question as to the involvement of a mononuclear or binuclear $\mathrm{Ni}$ site for the reaction. Fontecilla suggests a $\mathrm{Ni}(0)$ species and a mononuclear site [131].

A related mechanism was proposed by Wächtershäuser [174] for the formation of the activated thioester $\mathrm{H}_{3} \mathrm{C}-\mathrm{C}(\mathrm{O})-\mathrm{SCH}_{3}$ from $\mathrm{CO}$ and $\mathrm{CH}_{3} \mathrm{SH}$ on coprecipitated 


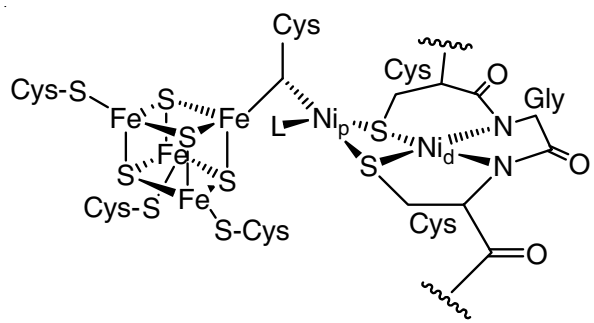

Scheme 1.19 Representation of the ACS active site. The site distal to the $\left(\mathrm{Fe}_{4} \mathrm{~S}_{4}\right)$ cluster is occupied by a $\mathrm{Ni}(\mathrm{II})$ ion in a square-planar environment $\left(\mathrm{Ni}_{\mathrm{d}}\right)$. $\left(\mathrm{Ni}_{\mathrm{p}}\right)$ is the catalytically relevant ion in the proximal site but its oxidation state is not clear. The coordination sphere of $\left(\mathrm{Ni}_{\mathrm{p}}\right)$ is completed by an unknown exogenous ligand L (adapted from [134]).

$\mathrm{NiS}$ and FeS. This $\mathrm{C}-\mathrm{C}$ coupling can be considered as a model reaction from the prebiotic formation of activated acetic acid at the beginning of life. Recently, Weigand, Kreisel et al. [156] observed the formation of ammonia from nitrogen and hydrogen sulfide at the surface of FeS, and at atmospheric nitrogen pressure. This is an important model reaction for the prebiotic production of ammonia.

Another example for the close analogy between biochemistry and organometallic chemistry is found in $\mathrm{CO}$ dehydrogenase which has an important ecological role [175]. Soil microbes exploit $\mathrm{CO}$ as a carbon and energy source and, using CODH, can remove this toxic gas from the environment at a rate of about $3 \times 10^{8}$ tons per year. According to the Hieber-base reaction, it is suggested that hydroxide (from iron) attacks a Ni coordinated CO ligand to give a metallocarboxylic acid which decomposes to give $\mathrm{CO}_{2}$ [133]. The original Hieber-base reaction involves the reaction of $\mathrm{Fe}(\mathrm{CO})_{5}$ with hydroxide [176] (Eq. 1.6).

$$
\mathrm{Fe}(\mathrm{CO})_{5}+\mathrm{OH}^{-} \rightarrow\left[\mathrm{Fe}(\mathrm{CO})_{4} \mathrm{COOH}\right]^{-} \rightarrow\left[\mathrm{Fe}(\mathrm{CO})_{5} \mathrm{H}\right]^{-}+\mathrm{CO}_{2}
$$

This reaction was reported in 1932 and led to the first carbonyl metal hydride, $\mathrm{H}_{2} \mathrm{Fe}(\mathrm{CO})_{4}$. The Hieber-base reaction was first interpretated by Kruck [177], and it is now the accepted mechanism for the metal-catalyzed water gas shift reaction (Eq. 1.7).

$$
\mathrm{CO}+\mathrm{H}_{2} \mathrm{O} \rightleftharpoons \mathrm{CO}_{2}+\mathrm{H}_{2}
$$

Twenty-five years ago Thauer [178] reported that the growth of methaneproducing bacteria (methane from $\mathrm{H}_{2}$ and $\mathrm{CO}_{2}$ ) was influenced by a nickelcontaining tubule. This observation finally led to the isolation of Ni complexes from methanogenic bacteria and to their characterization as Ni macrocycles with a reduced porphyrinoid ring (cofactor $\mathrm{F}_{430}$ ) [179]. The active enzyme contains $\mathrm{Ni}(\mathrm{I})$ at which the methyl groups can be oxidatively added. Methane is released by protonation of the $\mathrm{Ni}^{-\mathrm{CH}_{3}}$ species. Many laboratory examples are known whereby methylating agents can be added to metals in low oxidation states; the formation 
of methane from methyl complexes is also well known [180]. The importance of the methane-producing microorganisms stems from the fact that they release $10^{9}$ tons of methane into the atmosphere every year. However, the anaerobic oxidation of methane has also been reported [179b].

Finding good organometallic models able to take into account the behavior of organometallic enzymes remains a major goal for the chemist. At present the particular relevance of the model chosen often proves to be a key consideration. Novel multidisciplinary approaches are starting to appear, however, and their complexity may provide new sources of inspiration for research. As an example, Böck recently posed the following question: how did nature tame toxic ligands such as $\mathrm{CO}$ and $\mathrm{CN}^{-}$so as to fix them on the iron atoms of hydrogenases? [181]. Böck showed that in the biosynthesis of cyanide ligands in $\mathrm{Ni}-\mathrm{Fe}-\mathrm{H}_{2}$ ases the $\mathrm{CN}^{-}$ ligand is never free. The key step, after the synthesis of 27 , followed by that of $\mathbf{2 8}$ (Eq. 1.8), is a chemical transfer of $\mathrm{CN}$ towards the active centre of the protein $\mathrm{Ni}-\mathrm{Fe}-\mathrm{H}_{2}$ ase (with $\mathrm{L}_{\mathrm{N}}$ representing the coordination sphere of the active site).

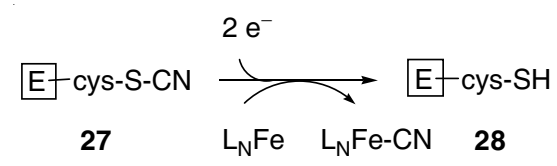

The thiocyanate residue is transported towards the active site, and the transfer of the electrophilic $\mathrm{CN}$ entity to the nucleophilic centre of the iron (or vice versa) occurs to form the $\mathrm{Fe}-\mathrm{CN}$ unit of the enzyme. This seminal work required a combination of radioisotopic labeling, mass spectrometry and reaction modeling studies. Thus, treating phenylthiocyanate with $\left[\left(\eta^{5}-\mathrm{C}_{5} \mathrm{H}_{5}\right) \mathrm{Fe}(\mathrm{CO})_{2} \mathrm{Br}\right]$ produces $\left[\left(\eta^{5}\right.\right.$ $\left.\mathrm{C}_{5} \mathrm{H}_{5}\right) \mathrm{Fe}(\mathrm{CO})_{2} \mathrm{CN}$ ] in good yield and under very mild conditions [15].

Monoxygenases are widely distributed enzymes which catalyze dioxygen activation using two electrons and two protons, with the insertion of one oxygen atom from $\mathrm{O}_{2}$ into a substrate and the formation of water according to Eq. (1.9).

$$
\mathrm{RH}+\mathrm{O}_{2}+2 \mathrm{e}^{-}+2 \mathrm{H}^{+} \rightarrow \mathrm{ROH}+\mathrm{H}_{2} \mathrm{O}
$$

A great number of these monooxygenases contain a heme protein called cytochrome P-450 which is the site of diooxygen activation. These cytochrome-P450-dependent monooxygenases are involved in many steps of the biosynthesis and biodegradation of endogeneous compounds such as steroids, fatty acids, prostaglandins and leukotrienes. They also play a key role in the oxidative metabolism of exogenous compounds such as drugs and other enviromental products allowing their elimination from living organisms. Because of their wide distribution in living organisms and their very important role in biochemistry, pharmacology and toxicology, cytochromes P-450 have been the subject of many studies during the last 20 years $[182,183]$. For these reasons, the organometallic chemistry of the P-450 cytochromes, widely covered elsewhere, will not be revisited here. This chemistry was started by two groups, that of D. Mansuy on the porphyrin 
iron carbene complexes [12] and that of R. Guilard on $\sigma$-alkyl type complexes [184]. For leading references see [185-191].

The cytochrome P-450 and iron porphyrins exhibit a particular ability to stabilize iron-nitrene and iron-carbene complexes which are formally the nitrogen and carbon equivalents of iron-oxo complexes. Many iron-carbene complexes, $\mathrm{Fe}=\mathrm{CRR}^{\prime}$, have been obtained either by in situ reduction of polyhalogenated compounds by iron (II) porphyrins in the presence of an excess of reducing agent, or by direct reaction between iron(II) porphyrins and some carbene precursors like diazo compounds. Among the few metalloporphyrins which have been found able to give stable metal-carbene complexes are $\mathrm{Ru}$ and Os porphyrins. On the contrary, $\mathrm{Ni}(\mathrm{II}), \mathrm{Co}(\mathrm{II})$ and $\mathrm{Rh}(\mathrm{III})$ porphyrins lead only to bridged carbene complexes upon reaction with carbene donors. These complexes are derived formally from the insertion of the carbene moiety into a metal-nitrogen (pyrrole) bond. Other model reactions indicate the importance of the organometallic chemistry of cytochrome P-450 where iron-carbon $\sigma$-bonds can also be formed.

A number of compounds containing carbon-halogen bonds, such as $\mathrm{CCl}_{4}$, $\mathrm{CF}_{3} \mathrm{CHClBr}$ (an anaesthetic agent marketed as halothane), benzyl halides etc. form carbenic or $\sigma$-bond complexes, depending on the nature of the reagent. However, other organometallic complexes of cytochrome P-450 may be formed as intermediates during the oxidation of various substrates, such as the epoxidation of propene. Finally, model systems of Fe and Mn are efficient oxidation catalysts, resistant to certain drugs and xenobiotics, and usable in fine chemistry (Scheme 1.20).
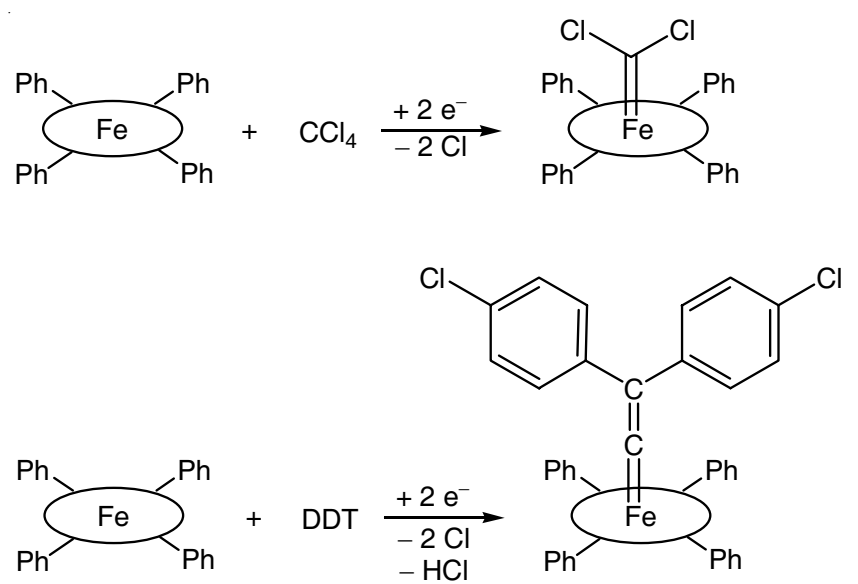

Scheme 1. 20 (Tetraphenylporphyrin) $\mathrm{Fe}=\mathrm{Cl}_{2}$ was synthesized from (TPPP) Fe and $\mathrm{CCl}_{4}$ in the presence of a reducing agent; an iron carbene complex from DDT has also been reported. 
1.6

Organometallic Chemistry and Aqueous Solvents

The compatibility of organometallic species with water, the essential biological solvent, is one of the conditions necessary for the advancement of the discipline. This is shown clearly in the case of anaerobic organometallic enzymes. But for chemists this has required a cultural change, despite the fact that water-soluble "oxo" catalysts of $\mathrm{Rh}$ bearing the $\mathrm{P}\left(\mathrm{m}-\mathrm{C}_{6} \mathrm{H}_{4} \mathrm{SO}_{3} \mathrm{Na}\right)_{3}$ ligand are commercially produced. Aqueous organometallic chemistry [192] is a new and challenging area and ranges from life science to catalysis [198]. The area of organometallic radiopharmaceuticals is particularly representative of this need for compatibility. R. Alberto, one of the principal researchers in this area, deals with this question in Chapter 4.

Here we will recall just two of the advances made in the field of radiopharmaceuticals over the last few years. One shining example of an organometallic pharmaceutical that has been successfully commercialized is technetium- $99 \mathrm{~m}$ sestamibi, a hexakis (alkylisocyanide) complex of ${ }^{99 \mathrm{~m}} \mathrm{Tc}$ (I) 29 that has become the most important myocardial imaging agent. The success of this compound, known by its trade name Cardiolite ${ }^{\circledR}$, has inspired researchers to develop other ${ }^{99 \mathrm{~m}}$ Tc-based radiopharmaceuticals [193-197].

${ }^{99 \mathrm{~m}}$ Tc bioorganometallic compounds have to be prepared in water from the readily available precursor, $\left[{ }^{99 \mathrm{~m}} \mathrm{TcO}_{4}\right]^{-}$, and the synthesis should also be rapid because ${ }^{99 \mathrm{~m}} \mathrm{Tc}$ has a half-life of about six hours. In addition, the preparation needs to be quantitative and simple to carry out, with the product solutions ready to inject into the patient.

Alberto has developed a method for directly converting $\left[{ }^{99 \mathrm{~m}} \mathrm{TcO}_{4}\right]^{-}$into $\left[{ }^{99 \mathrm{~m}} \mathrm{Tc}\left(\mathrm{OH}_{2}\right)_{3}(\mathrm{CO})_{3}\right]^{+} \mathbf{3 0}$, which has attracted much interest as a versatile precursor for ${ }^{99 \mathrm{~m}}$ Tc radiopharmaceuticals. This water- and air-stable aquo-carbonyl complex 30 contains three labile water ligands that can easily be substituted with a wide

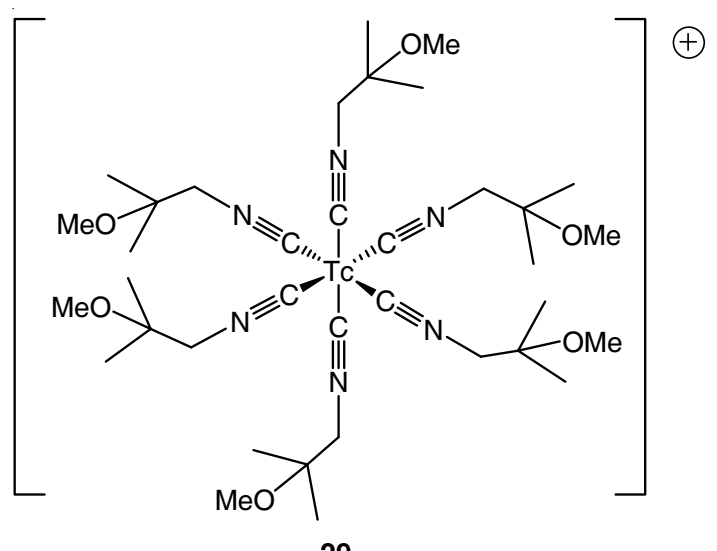

29

Scheme 1.21 Molecular structure of ${ }^{99 \mathrm{~m}} \mathrm{Tc}$-sestamibi (Cardiolite ${ }^{\circledR}$ ) 


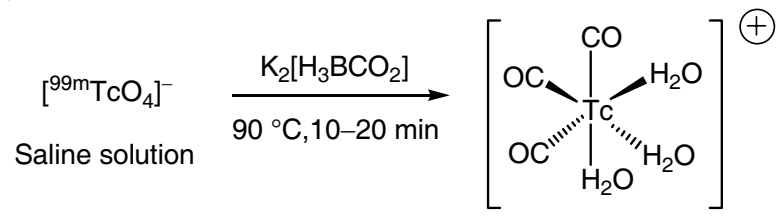

$30(>98 \%)$

Scheme 1.22 One-pot synthesis of the Alberto's reagent 30.

variety of organic ligands, thus providing a family of carbonyl complexes that can be used in life sciences and nuclear medicine applications [198-202].

As for organometallic amino acids, the peptides modified with them, and indeed the proteins and carbohydrates, their water solubility is a primary characteristic in terms of their use.

The first organometallic complex with an $\alpha$-amino acid, $\mathrm{Fe}(\mathrm{CO})_{2}$ (cysteinate $)_{2}$, was reported in 1929 by Cremer [203], and characterized by Schubert [204]. The first amino acid containing ferrocene was reported as long ago as 1957 by Schlögl [205], and Pauson [206]. For a comprehensive review on ferrocenyl bioorganometallics see [207]. The pioneering work of Schlögl was later developed by Sergheraert and Tartar [208] and others [7, 209]. Hieber et al. [210] used the halo-bridged complex $\left[\mathrm{M}(\mathrm{NO})_{2} \mathrm{Br}\right]_{2}$ with amino acids for the synthesis of the corresponding N,O-aminocarboxylates. The reaction of halobridged complexes was extremely useful for the preparation of many organometallic complexes of bioligands [7, 209]. Among the first organometallic complexes of $\alpha$-amino acids were the palladium and platinum complexes (allyl) $\mathrm{Pd}\left(\mathrm{NH}_{2} \mathrm{CHRCO}_{2}\right)$ [211] and $\left[\mathrm{Pt}(\mathrm{Cl})\left(\mathrm{NH}_{2} \mathrm{CHRCO}_{2}\right)\right.$ (olefin)], and the first half sandwich complexes with an $\alpha$-aminocarboxylate ligand $\left[\left(\eta^{6}-\mathrm{C}_{6} \mathrm{H}_{6}\right)\left(\eta^{3}\right.\right.$-allyl $\left.) \mathrm{Mo}\left(\mathrm{NH}_{2} \mathrm{CHRCO}_{2}\right)\right]$ [212], $\left(\eta^{6}-\mathrm{C}_{6} \mathrm{H}_{6}\right) \mathrm{Ru}\left(\mathrm{NH}_{2} \mathrm{CHRCO}_{2}\right)(\mathrm{Cl})$ [213], $\mathrm{CpMo}(\mathrm{CO})_{2}\left(\mathrm{NH}_{2} \mathrm{CHRCO}_{2}\right)$ [214], and the complexes $\left[\mathrm{Cp}_{2} \mathrm{Mo}\left(\mathrm{NH}_{2} \mathrm{CHRCO}_{2}\right]^{+}\right.$[215] and $\mathrm{Rh}$ (diene) $\left(\mathrm{NH}_{2} \mathrm{CHRCO}_{2}\right)_{2}$ [216]. Sheldrick and Heeb [217], as well as the groups of Carmona, Grotjahn, Werner, and Beck [7] successfully prepared and structurally characterized half-sandwich complexes of $\alpha$-aminoacidates and small peptides. In these "Brunner type" [218] complexes, the metal is a chiral center and diasteromers arise with optically active $\alpha$-aminoacids (Scheme 1.23).
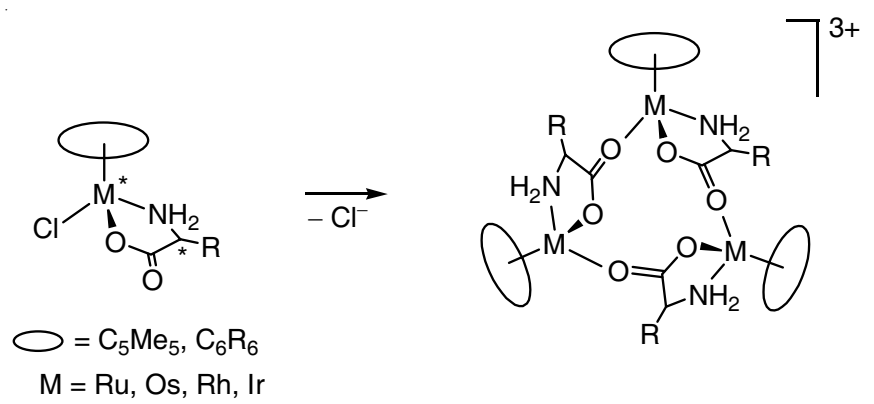

Scheme 1.23 Trimerization of metal complexes of amino acids. 
The carbonyl metal complexes which contain ligands of biological origin (nucleobases, amino acids) which were described before 1985 were reviewed by Ioganson [219], and the organometallic chemistry of amino acids and small peptides has been summarized by Beck, Bergs and Severin [7]. The Beck group in Munich has published more than 150 papers in this field and an example is shown on Scheme 1.24. Chapters 5 and 6 give additional examples of organometallic peptides and proteins with chemical, biochemical and biological aims.

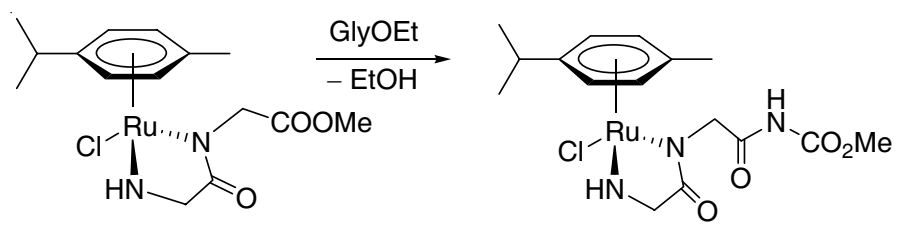

Scheme 1.24 Organometallic complexes of di- and tri-glycine.

Among the first organometallic complexes with nucleobases was a series of metal carbonyl complexes with these bioligands [220-222]. The structures of nucleobase-bridged carbonyl rhodium complexes were determined by Sheldrick [223], who also obtained a series of half-sandwich ruthenium complexes with nucleobases (Scheme 1.25) [224-226].<smiles></smiles>

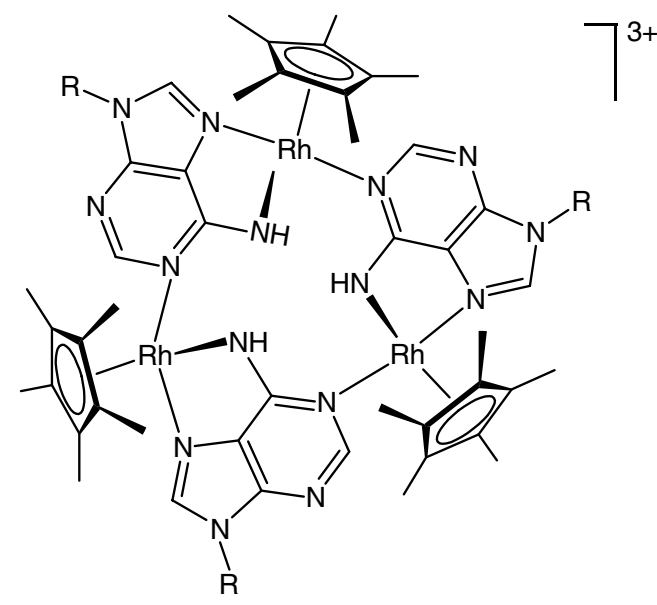

Scheme 1.25 Trimerization of a rhodium nucleobase complex.

Most of these primal studies with bioligands were mainly synthetic in their purpose and devoid of biological applications. However, they paved the way for further investigations. Ionic titanocene amino acid complexes $\left[\mathrm{Cp}_{2} \mathrm{Ti}\left(\mathrm{NH}_{2} \mathrm{CHRCO}_{2}\right)_{2}\right]^{+}$ show less pronounced antitumor activity $[227,228]$ than $\mathrm{Cp}_{2} \mathrm{TiCl}_{2}$ [227]. Recently, Sadler et al. [229] studied the antitumor activity of the organometallic ruthenium complexes that had first been observed by Sheldrick [230]. Chapter 10 includes other examples of nucleobases complexes displaying unusual supramolecular host-guest recognition properties. 
Among the first transition metal complexes (excluding $\mathrm{Hg}$ compounds) with metal-carbon $\sigma$-bonds to carbohydrates were cobalt carbonyl and $\mathrm{Cp}(\mathrm{OC})_{2} \mathrm{Fe}$ complexes [231-234]. These systems were also studied as intermediates in oxo reactions of unsaturated sugars [235-237]. Subsequently, metal carbene complexes of carbohydrates were synthesized [238-242]. In a series of papers, Dötz and coworkers [12, 243] introduced the "Fischer-type carbene functionality" into carbohydrates by using a number of different synthetic methodologies; these complexes can be used for the modification of sugars. Cyclopentadienyl-titanium complexes with chiral $\sigma$-coordinated ligands derived from glucose are stereoselective reagents in organic synthesis [244, 245]. A large number of chiral ligands derived from carbohydrates, mainly phosphines, are used in asymmetric catalysis [246-248]. The trimethylplatinum(IV) cation proved to be very well suited for the coordination of unprotected monosacharides (Scheme 1.26) [248].

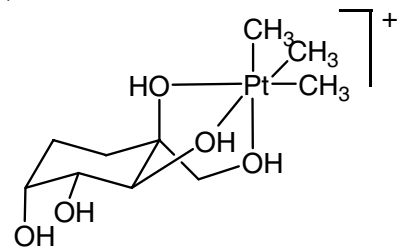

Scheme 1.26 A platinum complex of a carbohydrate.

Another topic related to water and organometallics has been developed by Fish, who is the author of Chapter 10. In particular, Fish has tried to overcome the problem of cofactor regeneration in biocatalysis. At least one-third of all known enzymes require the use of cofactors such as $\mathrm{NAD}^{+}$(nicotinamide adenine dinucleotide) and its reduced form, 1,4-NADH, to perform oxidations or reductions. However, these cofactors are expensive and fairly complicated molecules. It has been shown that, in aqueous solution, some organometallic biomimetic models behave chemically like $\mathrm{NAD}^{+}$and are able to abstract a hydride ion [249]. A key example is shown below where the hydride 33 reduces 31 into 34 (Scheme 1.27).
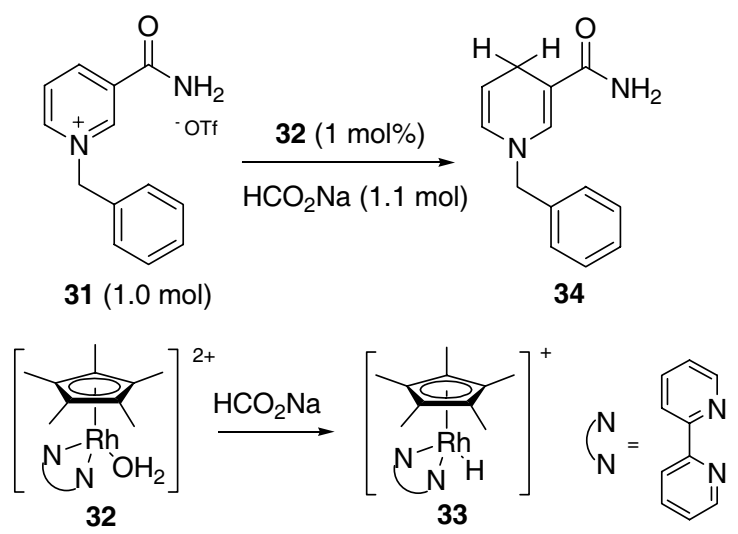

Catalyst precursor Hydride formation

Scheme 1.27 Organometallic cofactor model. 
1.7

\section{Conclusions}

The panoramic view presented here, which encompasses for the first time the many different aspects of bioorganometallic chemistry, makes it clear that the field now has a solid base from which extensive, multidisciplinary development can reliably be expected over the next few decades. The discipline benefits from a number of positive factors, including its ability to accommodate complexity and diversity, its use of a two-pronged scientific approach, the importance of the problems to be solved, the state of development of contemporary organometallic chemistry, the evolution of chemical thinking towards problems at interfaces and the amount of virgin terrain still to be explored. And perhaps above all, there is the opportunity offered to the imagination of the chemist in this science which, in Berthelot's words, "creates its own purpose".

Although bioorganometallic chemistry has already made great strides, there is much still on the horizon. There is no doubt that this avenue of research is capable of providing a source of inspiration and stimulating the creativity of chemists for the foreseeable future. In fact, some of the apparent obstacles to biological and biomedical applicability (aqueous solvents, time constraints for radiopharmaceuticals, anaerobic conditions, etc.), may be seen less as a brake than as a spur in the search for imaginative solutions.

The social relevance predicted for this discipline is another encouragement to its development. The range of potential commercial applications appears very promising, whether for environmental applications, bioanalysis, enzymology and biomimetic catalysis, in which the models are increasingly efficient, or indeed the development of novel therapies. The creation of new markets to provide solutions to problems yet to be defined will be one of the motors driving growth in this field, together with fundamental research.

The following chapters illustrate these points on several rapidly-evolving fronts which are worthy of attention for this reason alone. It is clear that the choice of topics is somewhat subjective, but this is counterbalanced by the opportunity it affords of presenting ideas within the context of a single body of work, an approach that will become more difficult as the discipline enjoys rapid expansion in the future. This emphasizes the importance of regular international conferences, such as those begun in Paris in 2002 and continued in Zurich in 2004, which can provide a much wider context for a dynamic view of bioorganometallic chemistry.

\section{Acknowledgments}

We wish to thank A. Vessières, S. Top and M. Salmain for constructive discussions and their help in editing the manuscript, and B. McGlinchey for her valuable linguistic expertise. G. J. thanks the von Humboldt foundation and the Institut Universitaire de France for beneficial awards. 


\section{References}

1 G. Jaouen, A. Vessières, Pure Appl. Chem. 1985, 57, 1865-1874.

2 S. Top, G. Jaouen, A. Vessières, J. P. Abjean, D. Davoust, C. A. Rodger, B. G. SAYer, M. J. McGlinchey, Organometallics 1985, 4, 2143-2150.

3 G. Jaouen, A. Vessières, I. S. Butler, Acc. Chem. Res. 1993, 26, 361-369.

4 A. D. Ryabov, Angew. Chem. Int. Ed. Engl. 1991, 30, 931-941.

5 R. H. Fish, Coord. Chem. Rev. 1999 , 185-186, 569-584.

6 D. Mansuy, Pure Appl. Chem. 1980, 52, 681-690.

7 K. Severin, R. Bergs, W. Beck, Angew. Chem. Int. Ed. 1998, 37, 1634-1654.

8 J. C. Fontecilla-Camps, S. W. Ragsdale, Adv. Inorg. Chem. 1999, 47, 283-333.

9 G. Jaouen, S. Top, A. Vessières, R. Alberto, J. Organomet. Chem. 2000, 600, 23-36.

10 M. Y. Darensbourg, E. J. Lyon, J. S. Smee, Coord. Chem. Rev. 2000, 206, 533-561.

11 F. Gloaguen, J. D. Lawrence, T. B. Rauchruss, J. Am. Chem. Soc. 2001, 123, 9476-9477.

12 K. H. DötZ, C. Jäckel, W. C. HaAse, J. Organomet. Chem. 2001, 617-618, 119-132.

13 W. BeCK, K. Severin, Chemie in unserer Zeit 2002, 6, 356-365.

14 R. H. Fish, G. Jaouen, Organometallics 2003, 22, 2166-2177.

15 L. D. Slep, F. Neese, Angew. Chem. Int. Ed. 2003, 42, 2942-2945.

16 D. C. Hodgkin, Proc. R. Soc. London, Ser. A 1965, 294.

17 W. KAIM, B. SCHWEDERSKI, in Bioinorganic Chemistry: Inorganic Elements in the Chemistry of Life, J. Wiley and Sons, 1994.

18 P. G. Lenhert, Proc. R. Soc. London, Ser. A 1968, 303, 45.

19 T. J. Kealy, P. L. Pauson, Nature 1951, 168, 1039-1040.

20 G. Wilikinson, M. Rosenblum, M. C. Whiting, R. B. Woodward, J. Am. Chem. Soc. 1952, 74, 2125-2126.

21 F. A. Соттоn, J. Organomet. Chem. 2001, 637-639, 18-26.
22 F. A. Сотton, G. Wilkinson, in Advanced Inorganic Chemistry, Wiley, 1962.

23 R. H. Crabtree, in The Organometallic Chemistry of the Transition Elements, Chap. 16, 2nd edition, J. Wiley and Sons, New York, 1994.

24 C. Elschentroich, A. Salzer, in Organometallics: a concise introduction, VCH, Weinheim, 1989.

25 In Acad. Roy. Sci. "Mémoires de mathématiques et de physiques", presented by various scientists, and read in their meetings, 1760 , t.III, pp. 623-637.

26 J. Flahaut, in Charles-Louis Cadet de Gassicourt (1761-1821), royal bastard, pharmacist to the Emperor, Ed. Historiques Tesseidre, Paris, 2001.

27 J. S. Thayer, Adv. Organomet. Chem. 1975, 13, 1-45.

28 L. G. Toraude, Ann. Sci. Chim. Phys. 1920, 1, 1-12.

29 R. W. Bunsen, Ann. Pharm. 1842, 42, 15

30 W. R. Cullen, Adv. Organomet. Chem. 1966, 4, 145-242.

31 J. B. Dumas, in his presentation of $R$. W. Bunsen as a foreign member of the Académie des Sciences in Paris (18 December 1882).

32 F. Himmelweit, in The collected papers of Paul Ehrlich, Vol. 3, Pergamon, London, 1960

33 J. Mann, in The Elusive Magic Bullet: the search for the perfect drug, Oxford University Press, Oxford, 1999.

34 J. E. Moore, in The Modern Treatment of Syphilis, 2nd edition, Thomas, pp. 64-133, Baltimore, 1941.

35 G. W. Raiziss, J. L. Gavron, in Organic Arsenical Compounds, Chem. Catalog. Co., pp. 492-513, New York, 1923.

36 D. W. Robertson, Trans. R. Soc. Trop. Med. Hyg. 1963, 57, 122-133.

37 B. Schmid, S. Nkunku, A. Merolle, P. Vouatsou, C. Burri, Lancet 2004, 364, 789-790.

38 A. Astier, S. Gibaud, French Patent, 0311919, 2003.

39 A. Konig, L. Wrazei, R. P. Warrell, R. Rivi, P. P. Pandolfi, A. JaKubowski, J. L. Gabrilove, Blood 1997, 90, 562-570. 
40 Z. G. WANG, R. Rivi, L. Delva, A. Konig, D. A. Scheinberg, C. Gambacorti-Passerini, J. L. Gabrilove, R. P. Warrell Jr., P. P. PANDOLFI, Blood 1998, 92, 1497-1504.

41 C. E. Carraher, C. U. Pittman, in Macromolecules Containing Metal and Metal-Like Elements, Vol. 3, pp. 2-16, John Wiley \& Sons, 2004.

42 B. Holmstedt, G. Liljestrand, in Readings in Pharmacology, pp. 22-30, Raven Press, New York, 1981.

43 F. C. Whitmore, in Organic Compounds of Mercury, Chem. Catalog. Co., pp. 368-372, New York, 1921.

44 J. S. THAYER, in Organometallic Compounds and Living Organisms, Academic Press, Orlando, 1984.

45 M. Peyrone, Ann. Chem. Pharm. 1844, Band LI, $1 \mathrm{ff}$.

46 B. Rosenberg, L. Vancamp, T. Krigas, Nature 1965, 205, 698-699.

47 B. Rosenberg, L. VANCAmp, J. E. Trosko, V. H. Mansour, Nature 1969, 222, 385-386.

48 B. Lippert, in Cisplatin: Chemistry and Biochemistry of a Leading Anticancer Drug, John Wiley and Sons, New York, 1999.

49 B. K. Keppler, in Metal Complexes in Cancer Chemotherapy, VCH, Weinheim, 1993.

50 Z. Guo, P. J. Sadler, Adv. Inorg. Chem. 2000, 49, 183-305.

51 M. J. Clarke, F. Zhu, D. R. Frasca, Chem. Rev. 1999, 99, 2511-2533.

52a J. ReEdijk, Chem. Commun. 1996, 801-806.

52b D. WAnG, S. J. Lippard, Nat. Rev. Drug Discov. 2005, 4, 307-320.

53 D. Carmona, M. P. Lamata, L. A. Oro, Eur. J. Inorg. Chem. 2002, 2239-2251.

54 A. H. Velders, A. Bergamo, E. Alessio, E. Zangrando, J. G. Hasnoot, C. Casarsa, M. Cocchietto, S. Zorget, G. SAVA, J. Med. Chem. 2004, 47, 1110-1121.

55 A. Bergamo, G. Stocco, C. Casarsa, M. Cocchietto, E. Alessio, B. Serli, S. Zorget, G. SAVA, Int. J. Oncol. 2004, 24, 373-379.

56 M. M. Harding, G. Mokdsi, Curr. Med. Chem. 2000, 7, 1289-1303.
57 P. Köpf-Maier, Eur. J. Clin. Pharmacol. 1994, 47, 1-16.

58 P. Köpf-Maier, H. Köpf, Chem. Rev. 1987, 87, 1137-1152.

59 J. B. WAERN, M. M. HARding, J. Organomet. Chem. 2004, 689, 4655-4668.

60 S. Top, E. B. Kaloun, A. Vessières, I. LAÏOS, G. LeCleRCQ, G. JaOUen, J. Organomet. Chem. 2002, 643-644, 350-356.

61 M. Tacke, L. T. Allen, L. Cuffe, W. M. Gallagher, Y. LoU, O. Mendoza, H. Müller-Bunz, F. J. K. ReHMANn, N. SweEney, J. Organomet. Chem. 2004, 689, 2242-2249.

62 M. Tacke, L. Cuffe, W. M. Gallagher, Y. Lou, O. Mendoza, H. Müller-Bunz, F. J. K. Rehmann, N. Sweeney, J. Inorg. Biochem. 2004, 98, 1987-1994.

63 C. S. Allardyce, P. J. Dyson, E. D. J. S. L. Heath, Chem. Commun. 2001, 1396-1397.

64 F. WAND, H. M. Chen, J. A. Parkinson, P. S. Murdoch, P. J. SAdler, Inorg. Chem. 2002, 41, 4509-4523.

65 C. S. Allardyce, P. J. Dyson, D. J. Ellio, P. A. Salter, R. Scopelliti, J. Organomet. Chem. 2003, 668, 35-42.

66 G. JaOuen, S. Top, J. P. Raynaud, French Patent 2725720-AI, 1994.

67 S. Top, J. TANG, A. Vessières, D. Carrez, C. Provot, G. Jaouen, Chem. Commun. 1996, 955-956.

68 S. Top, A. Vessières, G. LeClercQ, J. Quivy, J. TANG, J. VAissermann, M. Huché, G. Jaouen, Chem. Eur. J. 2003, 9, 5223-5236.

69 G. Jaouen, S. Top, A. Vessières, G. LeclercQ, M. J. McGlinchey, Curr. Med. Chem. 2004, 11, 2505-2517.

70 J. Brocard, J. Lebibi, L. Maciejewsi, French Patent 2733985-A1, 1996.

71 C. Biot, G. Glorian, L. A. Maciejewski, J. S. Brocard, J. Med. Chem. 1997, 40, 3715-3718.

72 C. Biot, L. Delhaes, H. Abessolo, O. Domarle, L. Maciejewski, M. Mortuaire, P. Delcourt, P. Deloron, D. Camus, D. Dive, J. Brocard, J. Organomet. Chem. 1999, 589, 59-65. 
73 С. Віот, Curr. Med. Chem. Anti-Infective Agents 2004, 3, 135-147.

74 P. J. CRAIG, in Organometallic Compounds in the Environment, 2nd ed., Wiley, Chichester, 2003.

75 T. TSubaki, K. Irukayama, in Minamata Disease: Methylmercury Poisoning in Minamata and Niigata Japan, Kodansha, Tokyo, 1977.

76 P. A. D'Itric, F. M. D'Itric, in Mercury Contamination; a Human Tragedy, Wiley, New York, 1997.

77 K. E. JaCKson, M. A. JaCKson, Chem. Rev. 1935, 16, 439-452.

78 F. W. Oенme, Clin. Toxicol. 1972, 5, 215-222.

79 R. A. Peters, L. A. Stockton, R. H. S. Thompson, Nature 1945, 156, 616.

80 C. J. Löwig, J. P. Chem. 1853, LX, 304.

81 S. K. Hall, Environ. Sci. Technol. 1972, 6, 30-35.

82 T. Alojouanine, L. Derbert, S. Thieffrey, Rev. Neurol. 1958, 98, 85.

83 J. E. Gruner, Rev. Neurol. 1958, 98, 104.

84 R. J. Fessenden, J. S. Fessenden, $A d v$. Organomet. Chem. 1980, 18, 275.

85 A. J. Growe, Chem. Int. (London) 1983, 304-310.

86 M. Tsutsui, N. Kakimoto, D. D. Axtell, H. Oikawa, K. Asai, J. Am. Chem. Soc. 1976, 98, 8287-8289.

87 J. S. Thayer, J. Organomet. Chem. 1974, 76, 265-295.

88 F. Challenger, Chem. Rev. 1945, 36, 315-361.

89 F. Challenger, Q. Rev. Chem. Soc. 1955, 9, 255.

90 R. S. Yalow, S. A. Berson, J. Clin. Invest. 1960, 39, 1157-1175.

91 R. S. Yalow, S. A. Berson, Nature 1959 , 84, 1648-1649.

92 R. EDWARDs, in Immunoassay, William Heinemann Medical Books, London, 1985.

93 T. J. Gill, L. T. Mann, J. Immunol. 1965, 96, 906-912.

94 J. P. Gosling, Clin. Chem. 1990, 36, 1408-1427.

95 L. J. KRICKA, in Ligand-Binder Assay, Marcel Dekker, New York, 1985.

96 M. Cais, S. Dani, Y. EdEN,

O. Gandolfi, M. Horn, E. E. IsaACs,

Y. JoSEPhy, Y. SAAR, E. SLOVIN,

L. SNARSKY, Nature 1977, 270, 534-535.
References $\mid 33$

97 J. F. Hainfield, Science 1987, 236, $450-453$.

98 J. H. W. Leuvering, B. C. Goverde, P. J. Thal, A. H. Schuurs, J. Immunol. Methods 1983, 60, 9-23.

99 P. Cheret, P. Brossier, Res. Commun. Chem. Pathol. Pharmacol. 1986, 54, 237-253.

100 K. Di Gleria, H. A. O. Hill, C. J. McNeil, Anal. Chem. 1986, 58, 1203-1205.

101 M. Salmain, A. Vessières, P. Brossier, I. S. Butler, G. Jaouen, J. Immunol. Methods 1992, 148, 65-75.

102 M. Cais, N. Tirosh, Bull. Soc. Chim. Belg. 1980, 90, 27-35.

103 P. Cheret, Ph D thesis, Université de Bourgogne, Dijon, 1987.

104 B. Limoges, C. Degrand, P. Brossier, R. L. Blankespoor, Anal. Chem. 1993, 65, 1054-1060.

105 D. H. FARKas, Clin. Chem. 2001, 47, 1871-1872.

106 S. D. Vernon, D. H. FARKAS, E. R. Unger, V. Chan, D. L. Miller, Y. P. Chen, G. F. Blackburn, W. C. Reeves, BMC Infectious Diseases 2003, 3/12, open access: http://www.biomedcentral.com/ 1471-2334/3/12.

107 C. J. Yu, Y. WAN, H. Yowanto, J. LI, C. TAO, M. D. JAMES, C. L. TAN, G. F. Blackburn, T. J. Meade, J. Am. Chem. Soc. 2001, 123, 11155-11161.

108 M. Salmain, A. Vessières, G. Jaouen, I. S. Butler, Anal. Chem. 1991, 63, 2323-2329.

109 I. S. Butler, A. Vessières, M. Salmain, P. Brossier, G. Jaouen, Appl. Spectrosc. 1989, 43, 1497-1498.

110 A. Vessières, S. Top, A. A. Ismail, I. S. Butler, M. Loüer, G. JaOuen, Biochemistry 1988, 27, 6659-6666.

111 G. Jaouen, A. Vessières, S. Top, A. A. Ismail, I. S. Butler, J. Amer. Chem. Soc. 1985, 107, 4778-4780.

112 A. Varenne, A. Vessières, P. Brossier, G. Jaouen, Res. Commun. Chem. Pathol. Pharmacol. 1994, 84, 81-92.

113 A. Varenne, A. Vessières, M. Salmain, P. Brossier, G. Jaouen, J. Immunol. Methods 1995, 186, 195-204.

114 A. Vessières, K. Kowalski, J. ZAKrZewski, A. Stepien, 
M. Grabowski, G. Jaouen, Bioconjugate Chem. 1999, 10, 379-385.

115 V. Philomin, A. Vessières, G. Jaouen, J. Immunol. Methods 1994, 171, 201-210.

116 A. Vessières, M. Salmain, P. Brossier, G. Jaouen, J. Pharm. Biomed. Anal. 1999, 21, 625-633.

117 Z. WANG, B. A. RoE, K. M. Nicholas, R. L. While, J. Am. Chem. Soc. 1993, 115, 4399-4400.

118 Y. Ueno, H. Yurimoto, H. Yoshioka, T. Komiya, S. Maruyama, Geochimica Cosmochimica Acta 2002, 66, 1257-1268.

119 R. J. P. Williams, J. J. R. Frausto DA Silva, J. Theor. Biol. 2003, 220, 323-343.

120 D. C. Rees, J. B. Howard, Science 2003, 300, 929-931.

121 W. Martin, M. J. Russell, Phil. Trans. R. Soc. London, Ser. B 2003, 358, 59-85.

122 J. A. Kovacs, S. C. Shoner, J. J. Ellison, Science 1995, 270, 587-588.

123 D. Dolphin, in B12, Vol. 1 and 2, Wiley Interscience, New York, 1982.

124 S. J. Lippard, J. M. Berg, in Principles of Bioinorganic Chemistry, Mill Valley, USA, 1994.

125 G. N. Schrauzer, Angew. Chem. Int. Ed. Engl. 1975, 15, 417.

126 S. GsChÖSSER, R. B. HANNAK, R. Konrat, K. Gruber, C. Miki, C. Kratky, B. KräUtler, Chem. Eur. J. 2005, 11, 81-93.

127 B. KräUtler, D. Arigoni, B. T. Golding, in Vitamin B12 and B12 proteins, Wiley-VCH Verlag GmbH, 1998

128 L. Randaccio, Comments Inorg. Chem. 2000, 21, 327-376.

129 O. Einsle, F. A. Tezcan,

S. L. Andrade, B. SCHMid, M. Yoshida, J. B. Howard, D. C. Rees, Science 2002, 297, 1696-1700.

130 J. Kim, D. C. ReEs, Science 1992, 257, 1677-1682.

131 C. Darnault, A. Volbeda, E. Kim, P. LEgRAND, X. VERnEDE, P. A. Lindahl, J. C. Fontecilla-Camps, Nat. Struct. Biol. 2003, 10, 446-451.

132 T. I. Doukov, T. Iverson, J. Sevaralli, S. W. Ragsdale, C. L. Drennan, Science 2002, 298, 567-572.

133 C. L. Drennan, J. W. Peters, Curr. Opin. Struct. Biol. 2003, 13, 220-226.

134 E. L. Hegg, Acc. Chem. Res. 2004, 37, $775-783$
135 A. D. Allen, F. Bottomley, Acc. Chem. Res. 1968, 1, 360-365.

136 J. Chatt, Chem. Soc. Rev. 1972, 1, 121.

137 J. Chatт, J. Organomet. Chem. 1975, 100, 17-28.

138 J. Chatt, J. R. Dilworth, R. L. Richards, Chem. Rev. 1978, 78, 589-625.

139 W. E. Newton, W. H. Orme-Johnson, in Nitrogen Fixation, University Park Press, Baltimore, 1980.

140 R. R. Schrock, J. Am. Chem. Soc. 1990 , 112, 4331-4338.

141 M. Stephenson, L. H. Stickland, Biochem. J. (London) 1931, 25, 205.

142 M. W. W. Adams, E. I. Stiefel, Curr. Opin. Chem. Biol. 2000, 214-220.

143 A. Volbeda, M. H. Charon, C. Piras, E. C. HATCHIKIAN, M. FREy, J. C. Fontecilla-Camps, Nature 1995 , 373, 580-587.

144 J. W. Peters, W. N. Lanzilotta, B. J. Lemon, L. C. Seffeldt, Science 1998, 282, 1853-1858.

145 H. Frey, ChemBioChem 2002, 3, 153-160.

146 Y. Nicolet, C. Piras, P. Legrand, C. E. Hatchikian, J. C. FontecillaCAmps, Structure 1999, 7, 13-23.

147 A. Volbeda, J. C. Fontecilla-Camps, Dalton Trans. 2003, 4030-4038.

148 M. Y. DAREnsbourg, E. J. Lyon X. Zhao, P. Georgakaki, Proc. Natl. Acad. Sci. USA 2003, 100, 3683-3688.

149 S. OTt, M. Kritikos, B. AKermark, L. Sum, R. Lомотн, Angew. Chem. Int. Ed. 2004, 43, 1006-1009.

150 T. B. Rauchfuss, Inorg. Chem. 2004, 43 , 14-26.

151 D. Sellmann, F. Geipel, F. Lauderbach, F. W. Heinemann, Angew. Chem. Int. Ed. 2002, 41, 632-634.

152 D. Sellmann, F. Lauderbach, F. Geipel, F. W. Heineman N Angew. Chem. 2004, 116, 3203-3206.

153 D. Sellmann, R. Prakash, F. W. Heinemann, Eur. J. Inorg. Chem. 2004, 1847-1858.

154 T. D. WeATHERILl, T. B. Rauchfuss, R. A. ScotT, Inorg. Chem. 1986, 25, 1466-1472.

155 L. F. DAhl, C. H. WeI, Inorg. Chem. 1963, 2, 334-336.

156 M. Dörr, J. Kässbohrer, R. Grunert, G. Kreisel, W. A. Brand, 
R. A. Werner, H. Geilmann, C. Apfel, C. Robl, W. Weigand, Angew. Chem. Int. Ed. 2003, 42, 1540-1543.

157 W. Hieber, W. Beck, Z. Anorg. Allg. Chem. 1960, 305, 265.

158 W. Hieber, J. Brendel, J. Gruber, Z. Anorg. Allg. Chem. 1958, 296, 68.

159 W. Hieber, P. Spacu, Z. Anorg. Allg. Chem. 1937, 233, 353.

160 W. Hieber, A. Zeidler, Z. Anorg. Allg. Chem. 1964, 329, 92.

161 R. B. King, J. Am. Chem. Soc. 1962, 84, 2460.

162 H. Reihlen, A. Gruhl, G. Hessling, Liebigs Ann. Chem. 1929, 472, 268.

163 D. Seyferth, R. S. Henderson, J. Am. Chem. Soc. 1979, 101, 508-509.

164 D. Seyferth, R. S. Henderson, L. C. Song, Organometallics 1982, 1, 125-133.

165 C. TARd, X. Liu, S. K. Ibrahim, M. Brushi, L. De Gioia, S. C. Davies, X. YANG, L. S. WANG, G. SAWERS, C. J. Pickett, Nature 2005, 433, 610-613.

166 P. A. Lindahl, J. Biol. Inorg. Chem. 2004, 9, 516-524.

167 S. W. Ragsdale, Biofactors 1997, 6, 3-9.

168 S. W. Ragsdale, M. Kumar, Chem. Rev. 1996, 96, 2515-2539.

169 R. K. Thauer, Science 2001, 293, 1264-1265.

170 J. Feng, P. A. Lindahl, J. Am. Chem. Soc. 2004, 126, 9094-9100.

171 J. FENG, P. A. LindAhl, Biochemistry 2004, 43, 1552-1559.

172 Y. Svetlitchnyi, H. DobbeK, W. Meyer-Klaucke, T. Meins, B. Thiele, P. Roner, R. Huber, O. Meyer, Proc. Natl. Acad. Sci. USA 2004, 101, 446-451.

173 S. S. Mansy, J. A. Conan, Acc. Chem. Res. 2004, 37, 719-725.

174 C. Huber, G. WÄchtershäuser, Science 1997, 276, 245-247.

175 G. M. KING, Appl. Environ. Microbiol. 2003, 69, 7266-7272.

176 W. Hieber, F. Leutert, Z. Anorg. Allg. Chem. 1932, 204, 145.

177 T. Kruck, M. Höfler, M. NoACK, Chem. Ber. 1966, 99, 1153.

178 P. Schönheit, J. Moll, R. K. Thauer, Arch. Microbiol. 1979, 123, 105-107.

179a R. K. Thauer, Microbiology 1998, 144, 2377-2406.
References | 35

179b M. KrÜGer, A. MeYerdlerks,

R. K. Thauer et al., Nature 2003, 426, 878-881.

180 W. BeCK, K. SünKel, Chem. Rev. 1988, 88, 1405-1421.

181 S. Reissmann, E. Hochleitner, H. Wang, A. Paschos, F. Lottspeich, R. S. Glass, A. Böck, Science 2003, 299, 1067-1070.

182 D. Mansuy, J. P. Mahy, in F. Montanari, L. Casella (Eds.), Metalloporphyrins Catalyzed Oxidations, p. 175-206, Springer, 1994.

183 P. R. Ortiz de Montellano, in Cytochrome P450, Plenum Press, New York, 1995.

184 P. Cocolios, G. Lagrange, R. Guilard, J. Organomet. Chem. 1983, 253, 65-79.

185 R. Guilard, K. M. Kadish, Chem. Rev. 1988, 88, 1121-1146.

186 R. Guilard, A. TABard, E. van Caemelbecke, K. M. Kadish, in K. M. Kadish, K. M. SMith, R. Guilard (Eds.), The Porphyrin Handbook, Vol. 3, p. 295-345, Academic Press, 2000.

187 D. Mansuy, Pure Appl. Chem. 1987, 59, 759-770.

188 D. Mansuy, Pure Appl. Chem. 1994, 66, 737-744.

189 D. Mansuy, M. Lange, J. C. Chottard, P. Guérin, P. Morlière, D. Brault, M. Rougee, Chem. Commun. 1977, 648-649.

190 D. Mansuy, W. NastainczyK, V. Ullrich, Arch. Pharmacol. 1974, 285, 315-324.

191 V. Ullrich, Top. Curr. Chem. 1979, 83, 67-104.

192 U. Koelle, Coord. Chem. Rev. 1994, 135-136, 623-650.

193 L. I. Delmon-Moingeon, D. Piwnica-Worms, A. D. VAN DEN Abbeele, B. L. Holman, A. Davison, A. G. Jones, Cancer Res. 1990, 50, 2198-2202.

194 B. L. Holman, V. Sporn, A. G. Jones, S. T. Benjamin-Sia, N. Perez-Balino, A. Davison, J. Lister-James, J. F. Kronauge, A. E. A. Mitta, L. L. Camin, S. Cambell, S. J. Williams, A. T. Carpenter, J. Nucl. Med. 1987, 28, 13-18. 
195 A. G. Jones, M. J. Abrams, A. Davison, US Patent, $N^{\circ} 4,452,774$, Issued 6/5/84, 1984

196 A. G. Jones, M. J. Abrams, A. Davison, US Patent, $N^{\circ} 4,707,544$, Issued 11/17/87, 1987.

197 A. G. Jones, M. J. Abrams, A. Davison, US Patent, $N^{\circ} 4,826,961$, Issued 5/2/89, 1989

198 R. Alberto, Chimia 2003, 57, 56.

199 R. Alberto, K. Ortner, N. Wheatley, R. Schibli, A. P. Schubiger, J. Am. Chem. Soc. 2001, 123, 3135-3136.

200 R. Alberto, R. Schibli, R. Waibel, U. Abram, A. P. Schubiger, Coord. Chem. Rev. 1999, 192, 901-919.

201 J. K. Pak, P. Benny, B. Spingler, K. Ortner, R. Alberto, Chem. Eur. J. 2003, 9, 2053-2061.

202 B. Salignac, P. V. Grundler, S. Cayemittes, U. Frey, R. Scopelliti, A. E. Merbach, R. Hechinger, K. Hegetschweiler, R. Alberto, U. Prinz, G. RaAbe, U. Koelle, S. Hall, Inorg. Chem. 2002, 42, 3516-3526.

203 W. Cremer, Biochem. Z. 1929, 206, 208.

204 M. P. Schubert, J. Am. Chem. Soc. 1933, 55, 4563-4570.

205 K. SCHLöGL, Monatsh. Chem. 1957, 88, 601.

206 J. M. Osgerby, P. L. Pauson, J. Chem. Soc. 1958, 656-660.

207 D. R. van Staveren, N. Metzler-Nolte, Chem. Rev. 2004, 104, 5931-5985.

208 E. Cuingnet, C. Sergheraert, A. Tartar, M. Dautrevaux, J. Organomet. Chem. 1960, 195, 325-329.

209 K. Severin, Chem. Eur. J. 2002, 8, 1515-1518.

210 W. Hieber, H. Führling, Z. Anorg. Allg. Chem. 1971, 381, 235.

211 E. Benetti, G. Maglio, R. Palumbo, C. Pedone, J. Organomet. Chem. 1973, 60, 189-195.

212 M. L. H. Green, L. C. Mitchard, W. E. Silverthorn, J. Chem. Soc. Dalton Trans. 1973, 1403-1408.

213 D. F. Dersnah, M. C. BAIRd, J. Organomet. Chem. 1977, 127, C55-C58.

214 W. Beck, W. Petri, J. Organomet. Chem. 1977, 127, C40-C44.

215 E. S. Gore, M. L. H. Green, J. Chem. Soc. A 1970, 2315-2319.
216 C. Potvin, L. Davignon, G. Pannetier, Bull. Soc. Chim. Fr. 1975, 507-511.

217 W. S. Sheldrick, S. Heeb, J. Organomet. Chem. 1989, 377, 357-366.

218 H. Brunner, Angew. Chem. Int. Ed. 1999, 38, 1194-1208.

219 A. A. Ioganson, Russ. Chem. Rev. 1985, 54, 277.

220 D. W. Аввотт, C. Watts, Inorg. Chem. 1983, 22, 597-602.

221 W. Beск, K. Kottmair, Chem. Ber. 1976 109, 970-993.

222 M. M. Singh, Y. Rosopulos, W. BeCK, Chem. Ber. 1983, 116, 1364.

223 W. S. Sheldrick, B. Guenther, Inorg. Chim. Acta 1988, 151, 237-241.

224 P. Annen, S. Schildberg, W. S. Sheldrick, Inorg. Chim. Acta 2000, 307, 115-124.

225 D. Herebian, W. S. Sheldrick, J. Chem. Soc. Dalton Trans. 2002, 966-974.

226 S. Korn, W. S. Sheldrick, Inorg. Chim. Acta 1997, 254, 85-91.

227 P. Köpf-MAier, H. Köpf, in Metal Complexes in Cancer Therapy, Chapman Hall, London, 1994.

228 P. Köpf-Maier, I. C. TORNieporthOetting, Biometals 1996, 9, 267-271.

229 F. Wang, H. Chen, S. Parsons, I. D. H. Oswald, J. E. Davidson, P. J. Sadler, Chem. Eur. J. 2003, 9, 5810-5820.

230 W. S. Sheldrick, S. Heeb, Inorg. Chim. Acta 1990, 168, 93-100.

231 H. H. Baer, H. R. Hanna, Carbohydr. Res. 1982, 102, 169-183.

232 J. M. Beau, T. Gallagher, Top. Curr. Chem. 1997, 187, 1-54.

233 A. Rosenthal, H. J. Кoch, Tetrahedron Lett. 1967, 8, 871-874.

234 G. L. Trainor, J. Organomet. Chem. 1985, 282, C43-C45.

235 I. Arai, G. D. Daves, J. Am. Chem. Soc. 1981, 103, 7683.

236 L. Jessen, E. T. K. Haupt, J. Heck, Chem. Eur. J. 2001, 7, 3791-3797.

237 Y. NAGEL, W. BECK, Z. Naturforsch. 1985 40b, 1181.

238 R. Aumann, Chem. Ber. 1992, 125, 2773-2778.

239 R. Aumann, Chem. Ber. 1994, 127, 725-729.

240 H. Fischer, J. Schleu, G. Roth, Chem. Ber. 1995, 128, 373-378. 


\section{References 37}

241 S. Krawielitzki, W. Beck, Chem. Ber. Rec. 1997, 130, 1659.

242 T. Pill, K. Polborn, W. Beck, Chem. Ber. 1990, 123, 11-17.

243 K. H. Dötz, E. Gomes de Silva, Synthesis 2003, 1787-1789.

244 R. O. Duthaler, A. Hafner, P. L. Alsters, P. Rothe-Streit, G. Rins, Pure Appl. Chem. 1992, 64, 1897-1910.
245 M. Riediker, R. O. Duthaler, Angew. Chem. Int. Ed. Engl. 1989, 28, 494-495.

246 M. Diéguez, O. Pamies, C. Clever, Chem. Rev. 2004, 104, 3189-3216.

247 H. Junicke, D. Steinborn, Inorg. Chim. Acta 2003, 346, 129-136.

248 D. Steinborn, H. Junicke, Chem. Rev. 2000, 100, 4283-4318.

249 H. C. Lo, C. Leiva, O. Buriez, J. B. KerR, M. M. Olmstead, R. H. Fish, Inorg. Chem. 2001, 40, 6705-6716. 
